\title{
Toraks difüzyon manyetik rezonans görüntüleme
}

Adem KARAMAN ${ }^{1}$
Mustafa KAHRAMAN $^{2}$
Erol BOZDOĞAN
Fatih ALPER
Metin AKGÜN

${ }^{1}$ Atatürk Üniversitesi Tıp Fakültesi, Radyoloji Anabilim Dalı, Erzurum, Türkiye

${ }^{1}$ Department of Radiology, Faculty of Medicine, Ataturk University, Erzurum, Turkey

${ }^{2}$ Erzurum Bölge Eğitim ve Araştırma Hastanesi, Radyoloji Bölümü, Erzurum, Türkiye

${ }^{2}$ Department of Radiology, Erzurum Regional Training and Research Hospital, Erzurum, Turkey

3 Özel Sevgi Can Hastanesi, Radyoloji Bölümü, Adana, Türkiye

${ }^{3}$ Department of Radiology, Private Sevgi Can Hospital, Adana, Turkey

${ }^{4}$ Atatürk Üniversitesi Tıp Fakültesi, Aziziye Araştırma Hastanesi, Radyoloji Bölümü, Erzurum, Türkiye

${ }^{4}$ Department of Radiology, Faculty of Medicine, Ataturk University, Aziziye Research Hospital, Erzurum, Turkey

${ }^{5}$ Atatürk Üniversitesi Tıp Fakültesi, Aziziye Araştırma Hastanesi, Göğüs Hastalıkları Bölümü, Erzurum, Türkiye

${ }^{5}$ Department of Chest Diseases, Faculty of Medicine, Ataturk University, Aziziye Research Hospital, Erzurum, Turkey

\section{ÖZET}

Toraks difüzyon manyetik rezonans görüntüleme

Toraksta manyetik rezonans görüntüleme (MRG) ile sadece morfolojik değerlendirme yapabilmekteyken artık günümüzde difüzyon ağırlıklı görüntüleme gibi fonksiyonel incelemeleri de kullanabilmekteyiz. Hareketi azaltıcı yazılımlar, çoklu kanal kullanımı, paralel görüntüleme ve hızlı sekanslar gibi yeni teknolojiler sayesinde toraksta artık doyurucu kalitede görüntüler alınmaktadır. Son yıllarda çok sayıda toraks MRG çalışmalarında umut verici sonuçlar yayınlanmıştır. Radyasyon içermediği için bazı endikasyonlar da bilgisayarlı tomografinin alternatifi olabileceği görülmektedir. Bu derlemede difüzyon MR incelemenin akciğer ve mediasten patolojilerinde hangi durumlarda nasıl uygulandı̆̆ıla ilgili yapılan güncel çalışmaları gözden geçirdik ve toraks patolojilerinin tanımlanmasında, karakterizasyonunda ne tür bilgiler sağladığını ortaya koymaya çalışık.

Anahtar kelimeler: Difüzyon MRG, toraks, nodül, kanser

\section{SUMMARY}

\section{Diffusion magnetic resonance imaging of thorax}

Although magnetic resonance imaging (MRI) of Thorax is only useful for morphological evaluation, currently we can use it for functional evaluation such as diffusion weighted imaging. Currently, we can obtain higher quality images because of new technologies such as software that decrease motion artefact, use of multi-channel, parallel imaging and fast sequences. Many promising results of thorax MRI have been published. It may also be an alternative to

\section{Yazışma Adresi (Address for Correspondence)}

Dr. Adem KARAMAN

Atatürk Üniversitesi Tıp Fakültesi, Radyoloji Anabilim Dalı, ERZURUM - TURKEY

e-mail: drkaraman77@yahoo.com 
thorax computed tomography in some indications without radiation exposure risk. In this review, we evaluated current literature on use of DWI MRI examination on the pathologies of lungs and mediastinum and aimed to present what kind of information is provided on recognition and characterization of thoracic pathologies.

Key words: Diffusion MRI, thorax, nodule, cancer

\section{GiRiş}

Manyetik rezonans görüntülemenin (MRG) toraksta kullanımı son yıllarda giderek artmaktadır. Toraksta solunum-kalp hareketleri, vasküler atımlar, hava ve dokulardaki arayüzlerden kaynaklanan duyarlılık artefaktları ile akciğerlerdeki düşük yoğunluktan kaynaklanan düşük proton miktarı MRG kullanımında önemli kısıtlayıcılardır. Önceleri toraksta sadece morfolojik değerlendirme yapılabilirken, teknolojinin gelişmesi sonucu, difüzyon ağırlıklı görüntüleme (DAG), perfüzyon ağırlıklı görüntüleme, hareketli sine MRG ve ventilasyon-perfüzyon gibi fonksiyonel görüntüleme yöntemleri rutin kullanıma girmeye başlamıştır. Radyasyon riski olmadığı için MRG ile aynı hastaya çok sayıda tetkik yapılabilmekte, takipte bilgisayarlı tomografiye (BT) alternatif olabilecek bilgi verebilmektedir. Bu yüzden toraksta MR kullanımının giderek yaygınlaştığı görülmektedir.

Toraks patolojilerine yönelik güncel tanı rehberlerindeki algoritmalarda yaygın olarak direkt grafi, BT ve pozitron emisyon tomografisi (PET)/BT bulunmaktadır $(1,2)$. MRG'de hareket artefaktını engelleyici yazıIımlar, çoklu kanal kullanımı, paralel görüntüleme ve hızlı sekanslar gibi yeni teknolojiler sayesinde toraksta artık istenilen kalitede görüntüler alınabilmektedir. Son yıllarda yapılan toraks MR çalışmaları ilerleyen zamanlarda $M R^{\prime}$ ın toraks patolojilerinin tanı rehberlerindeki yerinin ve öneminin daha da artacağını göstermektedir.

Toraksta rutin olarak alınan T1, T2, "Short Time Inversion Recovery (STIR)", "Steady State Gradient Echo" sekansları ve kontrastlı seriler morfolojik açıdan önemli bilgiler vermektedir. Ancak bulguların çoğunlukla nonspesifik olması ve morfolojik bilgi düzeyinde kalması nedeniyle ilave sekanslara ihtiyaç duyulmaktadır. Fonksiyonel değerlendirme olanağı veren DAG özellikle akciğerin primer ve metastatik tümöral patolojileri ile lenf nodlarının değerlendirilmesine tanısal açıdan önemli role sahiptir. Bu derlemede difüzyon MRG'de akciğer, mediasten ve göğüs duvarı patolojilerindeki kullanım alanı ile ilgili yapılan güncel çalışmaları gözden geçirmeyi, toraks patolojilerinin tanımlanmasında ve karakterizasyonundaki rolünü ortaya koymaya çalıştık.

\section{DiFÜZYON AĞIRLIKLI GÖRÜNTÜLEMENIN PRENSIPLERI}

Difüzyon olarak kastedilen durum, su moleküllerinin termal enerjiyle doku içerisindeki rastgele mikroskobik hareketidir. DAG ise hücrenin mikro yapısında bilgi elde etmeye yardımcı olan fonksiyonel MRG tekniğidir. Difüzyon ağırlıklı görüntü elde etmek için en sık yağ baskılamalı "single shot spin-echo (SE)" ve "echo-planar" sekansları uygulanmaktadır. DAG'da b olarak isimlendirilen bir değer kullanılmaktadır. Bu değer artıkça difüzyon değeri de belirli bir seviyeye kadar artmaktadır. Ölçümler, ilk önce $b=0 \mathrm{sn} / \mathrm{mm}^{2}$ ve sonra incelenecek b değerleri olarak uygulanır, "b" değerinin değişmesi ise difüzyonun incelemedeki ağırlığını değiştirecektir. DAG'da çoğu araştırmacı genellikle $b$ değeri olarak $\left(\mathrm{s} / \mathrm{mm}^{2}\right) 0$ ve 1000 kullanmıştır. Ancak bazı araştırmacılar da 0/300/600, 50/400 ve 68/577 değerlerini kullanmışıı (3-5). Biz toraks çalışmalarında $b=0,500,1000$ veya $b=50,800$ değerlerini kullanmaktayız. "Apparent diffusion coefficient (ADC)" haritaları ise difüzyon incelemede bizlere sayısal değerler verebilmektedir (6).

Difüzyon ağırlıklı görüntülerde görüntünün yoğunluğu moleküllerin difüzyon kabiliyetleriyle artmakta veya azalmaktadır (7). Bu hareket normal ve patolojik dokular arasında farklılık gösterir. Yüksek ADC değerleri, yani difüzyonun normal veya arttığı durumlar, sağlıklı dokularda ya da benin patolojilerde görülür. Bu lezyonlarda geniş ekstraselüler alanlar ve hücre yoğunluğunda azalma vardır. Bunun tam tersi olarak difüzyonun kısıtlanması yani düşük ADC değerleri, hiperselülariteyi, sitotoksik ödemi veya yoğunlaşmış içeriği (hemoraji veya protein) gösterir. Malin hücrelerde çekirdek/sitoplazma oranının geniş hücre çekirdekleri nedeniyle artış göstermesi, oluşan hücre sayısındaki artış, makromoleküllerin kanser hücrelerindeki artışı ve hücreler arası mesafenin azalması gibi nedenlerden dolayı suyun hareket alanı daralmakta ve difüzyonu kısıtlanmaktadır. Buna bağlı olarak ADC değerlerinde düşüş saptanmaktadır. Bu özelliği nedeniyle DAG, malin-benin hastalık ayırıcı tanısında kullanılmaktadır. Ancak malin hastalarda nekroz nedeniyle difüzyonda yanıltıcı istenmeyen bir artışa neden olmakta veya malin olmayan hemorajik bir lezyonda difüzyon kısıtııı̆̆ı nedeniyle DAG'da beklenmeyen yanıltıcı sonuçlar oluşabilmektedir. 
Difüzyon MRG'de çok güçlü manyetik gradientler eşliğinde milisaniyeler içerisinde görüntü oluşturabilen sekanslar kullanarak su moleküllerinin hareketlerini görüntülemek mümkün olmaktadır. Toraksta DAG kullanımının en önemli handikapı solunum ve kalp hareketleri sonucu oluşan artefaktlardır. Ancak son yıllarda kardiyak ve solunumsal tetiklemeli çekimler ve hızlı çekim sekanslarının kullanımı bu durumun kısmen önüne geçilmiştir. Özellikle yeni MRG cihazlarında hareketi giderici yazılımlar geliştirilmiş olup, hem fonksiyonel incelemeler hem de kontrast sonrası yapılan eğrisel ölçümler daha hassas hale getirilmiştir. Görüntüler toraksta çoklu nefes tutmayla elde edilir (3-4 × 20 s). Eğer hasta nefes tutamıyorsa nefes tutmaksızın solunumsal tetikleme uygulanabilir ancak bu durum çekim süresini 4-5 dakika uzatır. Bu sekansta geometrik çözünürlük az olduğu için görüntü kalitesi rutin sekanslardan daha düşüktür. Manyetik rezonans protokol seçiminde DAG, toraks kitlelerinin değerlendirilmesinde (yaklaşık $20 \mathrm{dk}$ ) ve kitlenin vasküler invazyonunun araştırılmasında (yaklaşık $25 \mathrm{dk}$ ) incelemeye dahil edilmelidir (8). Bazı araştırmacılar ise DAG'da sekans olarak STIR-EPI veya "split acquisition of fast spin-echo signals for diffusion imaging (SPLICE)" sekansını kullanmışlardır.

Difüzyonda 1.5 ve üzeri tesla MRG'lerde başarılı sonuçlar alınabilmektedir Çekim sırasında oluşabilecek hareket artefaktlarını engellemek amacıla EKG probları kullanılarak çekim yapılabilmektedir. Önce MRG'de tüm toraks ve üst batını içerecek tarzda aksiyel düzlemde T2-trueFISP görüntüler (TR: $10.2 \mathrm{ms,}$ TE: $4.7 \mathrm{~ms}$ ) alınarak incelenecek bölge lokalize edilmektedir. Rutin konvansiyonel sekanslar aksiyel (T1, T2, STIR) elde olunmaktadır. Sonrasında b 50, 800 sekansları alınır. Toplam tetkik süresi yaklaşık 20 dakika olarak ayarlanmaktadır. DAG'da (TR: 4100 msn, TE: 81 msn, matriks: 195 x 156 ve kesit kalınlı$\breve{\mathrm{g}} \mathrm{I}=8 \mathrm{~mm}$, kesit boşluğ $\mathrm{u}=2 \mathrm{~mm}$ ) her bir kesit için 50 $\mathrm{mm}^{2} / \mathrm{sn}$ ve $800 \mathrm{~mm}^{2} / \mathrm{sn}$ olan b değerleri kullanılmaktadır. Değerler değişken olup b 1000 değeri de kullanılabilir.

Filmleri değerlendirme aşamasında öncelikle konvansiyonel T1, T2 ve STIR ağırlıklı görüntülerde lezyonun sinyal özellikleri, kenar yapısı, komşu dokularla olan ilişkileri ve varsa invazyonları değerlendirilir. Standart görüntülerle değerlendirmenin ardından yüksek b değerleri (800/1000) ve ADC haritaları incelenir. Değerlendirme, sadece görsel kalitatif olabileceği gibi ADC haritalarında ilgi alanı "region of interest (ROI)" ölçümleri kullanılarak kantitatif de yapılabilir. Difüzyonda kısıtlılık olduğunu söyleyebilmek için b 1000'de parlaklık yani hiperintensite ve $A D C^{\prime}$ de ise kararma yani hipointensite tesbit edilmiş olmalıdır. Tam tersi durumda ise serbest difüzyon veya difüzyonda artıştan bahsedilmelidir. Lezyonlara yerleştirilmiş ROI, eğer lezyon homojenite gösteriyorsa sadece bir alandan, heterojen davranış gösteriyor ise muhtelif bölgelerden birkaç defa örnekleme yapılarak değerlendirilmelidir. Yaklaşık ROI volümleri $0.2-4 \mathrm{~cm}^{2}$ aralığında olmaktadır. Ölçümlerde standart ROI kullanılabileceği gibi kas veya spinal kord ölçümleri göz önüne alınarak rölatif ROI da kullanılabilir (3-5,9-12). Rölatif ROI kullanılmasının başlıca nedeni her hastanın çekiminde manyetik alanın aynı homojeniteyi göstermemesi ve aynı hastada farklı zamanlarda yapılan çekimlerde doku intensitelerinin sabit olmamasıdır. Bu nedenle difüzyon MR değerlendirmede rölatif ROI değerlerinin daha anlamlı olduğu kabul edilmektedir.

\section{KLINIK KULLANIM ALANLARI}

\section{Akciğer Lezyonları}

Pulmoner nodüller: Güncel klinik uygulamalarda pulmoner nodül tanı ve takibinde genellikle BT kullanılmaktadır $(1,2)$. BT tetkikiyle yapılan kısa aralıklı takipler hastanın maruz kaldığı X ışını miktarını artırmakta ve özellikle kadın hastalarda radyasyona bağ ıı risk artışına neden olmaktadır (Resim 1,2). Bu durum pulmoner nodülün tanı ve takibinde yeni arayışlara gereksinim duyulmasına neden olmuştur. Konvansiyonel MR sekansları ve STIR ile yapılan çalışmalar pulmoner nodül tespitinde çok iyi sonuçlar vermiştir (13). Multidedektör bilgisayarlı tomografi (MDBT) ile karşılaştırmalı bir çalışmada ise 3 mm'den büyük nodüllerde $M R^{\prime} ı$ S STIR sekansının duyarlılığının daha fazla olduğu gösterilmiş̧ir (14). Malin lezyonlarda hücresel artış, dokunun daha düzensiz hale gelmesi ve ekstraselüler boşluktaki tortiozite artışı nedeniyle interstisyel suyun difüzyonu kısıtlanmaktadır (Resim 3,4).

Pulmoner nodüllerin karakterizasyonunda PET yararlı olmasına rağmen özellikle adenokarsinomlarda sınırI rolü bulunmakta, inflamatuvar patolojilerde ise yalancı pozitif sonuçlar vermektedir (15). Dinamik kontrastlı $M R$, nodüllerin benin ve malin ayrımında MDBT ve PET/BT'den daha iyi özgüllük ve doğruluk oranlarına sahiptir (16). Fakat dinamik kontrastlı MR incelemelerinde de bazı inflamatuvar patolojilerin malin nodüller gibi erken evre kontrast tutulumu göstermesi tanısal açıdan problem oluşturmaktadır (17).

Pulmoner nodüllerin DAG ile değerlendirip ve MDBT ile karşılaştırdığı bir çalışmada DAG görüntülerin duyarlılığının 5 mm'den küçük nodüllerde \%43.8; 


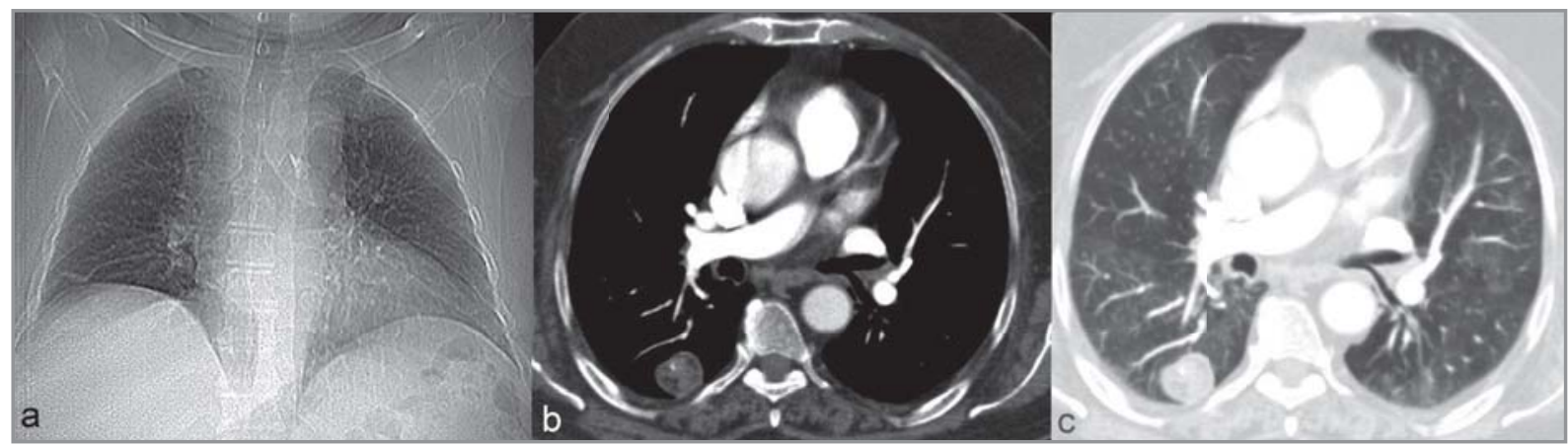

Resim 1. Yetmiş yedi yaşında hamartoma tanılı erkek hasta, (A) PA grafide sağ hilus üzerine süperpoze lezyon izlenmektedir, (B) Aksiyel kontrastlı BT'de mediasten penceresinde yağ dokusu ve kalsifikasyon içeren nodül, (C) Aksiyel kontrastlı BT'de parankim penceresinde düzgün kenarlı nodül.

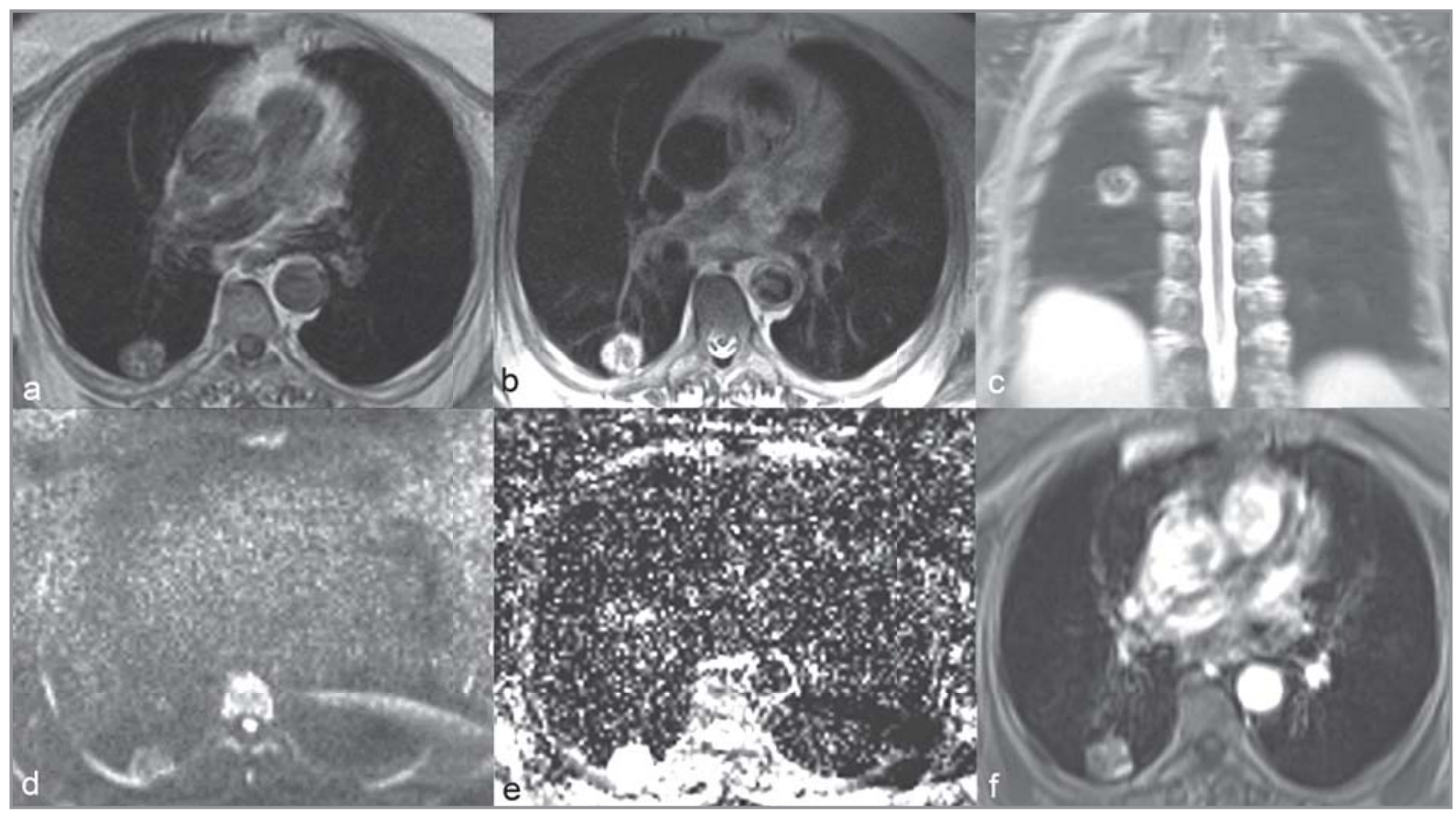

Resim 2. Yetmiş yedi yaşında hamartoma tanılı erkek hasta, (A) Aksiyel T1 ağıılıklı kesit, (B) Aksiyel T2 ağırlıklı kesit, (C) Koronal T2 ağırlıklı kesit, (D) Aksiyel b 800, (E) Aksiyel ADC harita ve (F) Aksiyel T1 ağırlıklı kontrastlı kesitlerde hafif heterojen intensitede, difüzyonda kısıtlılık göstermeyen, zayıf kontrast tutan nodüler lezyon.

6-9 $\mathrm{mm}$ boyutundaki nodüllerde \%86,4; $10 \mathrm{~mm}$ ve üzeri nodüllerde ise \%97.0 olduğu tespit edilmiştir (8). Sonuç olarak bu çalışmada DAG'ın 6 mm'den büyük nodüllerin tespitinde \%86.4 duyarlılığa sahip olduğu ve MDBT'nin yanlış pozitif sonuçlarını azaltabileceği öngörülmüştür. Aslında bu çalışmada DAG'ın fonksiyonel özelliğinden ziyade morfolojik özelliği kullanılmıştır (18). Küçük hücreli dışı akciğer kanserli (KHDAK) hastalarda tüm vücut DAG MR ile yapılan başka bir çalışmada ise DAG'ın 10 mm'den küçük 5 pulmoner metastazın 3'ünde negatif olduğu görülmüştür (19). Pulmoner adenokarsinomun tespitinde
STIR sekansının DAG'dan daha hassas olduğu bir çalışmada gösterilmiştir (17). Nodülün çapı ve görüntü kalitesi arttıkça DAG'ın duyarlılığı da artmaktadır.

Cerrahi öncesi 58 hastada, 58 malin ve 18 benin nodül hem 1.5 ve 3 Tesla MR ile hem de PET ile değerlendirilmiş, her 3 tetkikin de benin malin ayrımında benzer duyarlılık ve özgüllüğe sahip olduğu görülmüştür (18). Bu çalışmada kullanılan 1.5 ve $3 \mathrm{~T}$ MR ile alınan DAG'ın malin nodüllerin değerlendirilmesinde eşit derecede faydalı olduğu görülmüştür (20). Pulmoner metastazın tespitine yönelik olarak 


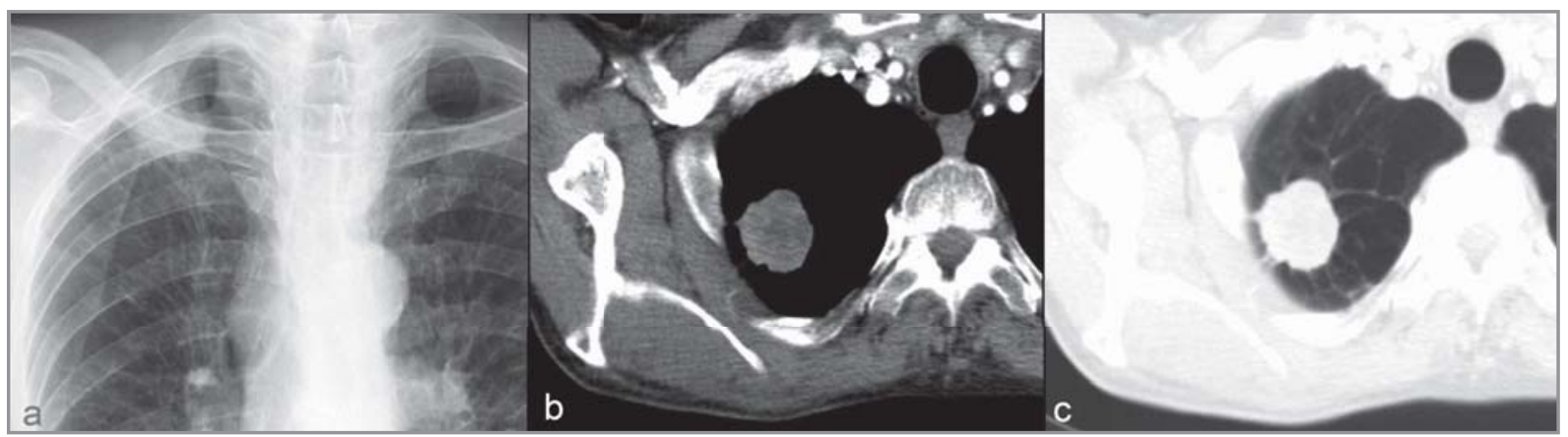

Resim 3. Yetmiş yedi yaşında yassı hücreli kanser olan erkek hasta, (A) PA grafide sağ akciğer üst lob apikal segmentte nodüler lezyon ve sağ paratrakeal çizgide kalınlaşma ve opasite artımı mevcuttur, (B) Aksiyel kontrastlı BT'de mediasten penceresinde ve (C) Parankim penceresinde sağ akciğer üst lob apikal segmentte düzensiz kenarlı, heterojen dansitede ve spiküler uzanımları olan nodüler lezyon görülmektedir. Ayrıca amfizematöz alanlarda dikkati çekmektedir.

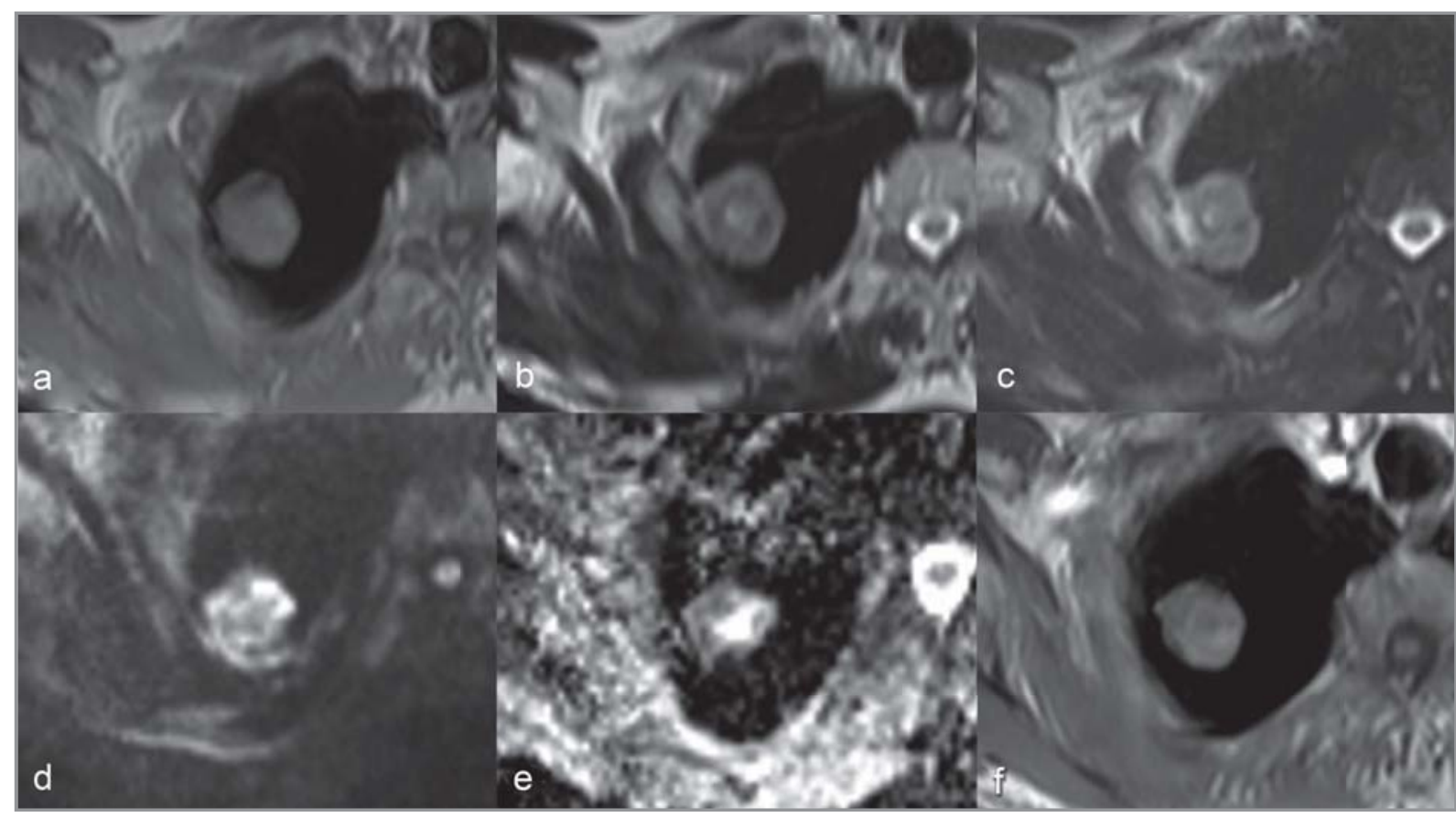

Resim 4. Yetmiş yedi yaşında yassı hücreli kanser olan erkek hasta, (A) Aksiyel T1 ağırlıklı kesit, (B) Aksiyel T2 ağılıklı kesit, (C) Aksiyel STIR kesiti, (D) Aksiyel b 1000, (E) Aksiyel ADC harita ve (F) Aksiyel T1 ağırlıklı kontrastlı kesitler 3 T MR ile alınmıştır. Sağ akciğer üst lobta apikal segmentte heterojen intensitede, spiküler kenarlı, STIR'da hiperintens alanlar içeren, difüzyonda belirgin kısıtlılık oluşturan, heterojen hafif derecede kontrast tutulumu gösteren nodüler lezyon izlenmektedir. Lezyon içerisinde difüzyonda artışa neden olan kistik veya nekrotik alan mevcuttur.

tüm vücut DAG ve PET/BT ile yapılan diğer çalışmalarda da benzer sonuçlar bulunmuştur (21).

Akciğer nodüllerinde malin benin ayrımı açısından b 1000 görüntülerde spinal korda göre 5 grupta görsel kıyaslama yapılan bir çalışmada; 51 hastada 54 nodül incelenmiştir. Difüzyon MRG'de duyarlılık \%88.9, özgüllük \%61.0 ve pozitif prediktif değer ise \%79.6 olarak tespit edilmiştir (12). Küçük metastatik nodüller ve solid olmayan adenokarsinom olmaması gereken düşük değerlerde skorlanırken (yalancı negatif), bazı granülomlar ve aktif inflamatuvar nodüller ise yanıltıcı olarak yüksek değerlerde skorlanmıştır (yalancı pozitif). Bu durumlar dışında difüzyon MRG malin ve benin ayrımında faydalı bilgiler vermektedir (12).

Operasyon öncesi 104 hastada (140 nodül/kitle) DAG ve PET bulguları karşılaştırılarak ADC değerleri 
ve SUV değerleri ölçülmüş, duyarlılığın her iki yöntemde eşit olduğu özgüllüğün ise $D A G^{\prime} d a$ daha yüksek olduğu bulunmuştur. Bu durum aktif inflamatuvar lezyonlarda DAG'da yanlış pozitiflik oranın daha düşük olmasına bağlanmış ve DAG'ın PET yerine kullanılabileceği öne sürülmüştür (22).

Malin-benin ayırımında ADC değerleri ile yüksek b değerlerinde, lezyon ve spinal korddan alınan değerlerin oranının (lezyon/spinal kord oranı, LSO) karşılaştırıldığı bir çalışmada; hastalarda b0 ve b1000 değerleri kullanılmış olup, bu değerlerle ADC haritalama yapılmıştır. Yirmi sekiz hastada $\mathrm{BT}^{\prime}$ de izlenen lezyonlar DAG ile incelenmiştir. Bu çalışmada malin nodüller ile benin nodüller arasında LSO değerlerinde istatistiksel anlamlı fark bulunmuş ancak ADC değerlerinde anlamlı fark bulunamamıştır. Eşik değeri olarak 1.135 kullanıldığında LSO'nun pozitif prediktif değeri \%93.8 ve negatif prediktif değeri \%75.0 olarak bulunmuştur (23).

Akciğer tümörleri: DAG; toraksta kitlelerin karakterizasyonu, tümör ile atelektazi, tümör ile postobstrüktif pnömoni ayrımı, erken dönemde kemoterapi yanıtının değerlendirilmesi ve tümör invazyonun tespiti gibi birçok alanda kullanılmaktadır (Resim 5). Akciğer tümörlerinde tümörün histopatolojik tipine göre farkIı oranlarda difüzyon kısıtlılıkları izlemekteyiz (Resim 6-12).

Periferik yerleşimli, plevral bağlantılı olan solid lezyonlu 36 hastanın değerlendirildiği tez çalışmasında, $\% 25^{\prime} \mathrm{i}$ benin ve $\% 75^{\prime} \mathrm{i}$ malin olan lezyonlar değerlendirilmiştir. Çalışmada ADC değerlerinden alınan, lezyondan alınan ROI ile lezyon ile aynı kesitte yer alan paraspinal kaslardan alınan ROI değerlerinin oranlandığı, ortalama rölatif ROI değerleri kullanılmıştır. Ortalama rölatif ROI oranı benin lezyonlarda $2.23 \pm 0.50$, malin lezyonlarda ise $1.10 \pm 0.37$ olarak ölçülmüştür. Sonuç olarak solid lezyonların malin-benin ayırımında rölatif ROI oranlarının malin lezyonlarda benin olanlara göre istatistiksel olarak anlamlı farklı olduğu bulunmuştur (11).

Başka bir çalışmada iyi diferansiye adenokarsinomların diğer histopatolojik tiplere göre daha yüksek ADC değerlerine sahip olduğu gösterilmiş ve ADC değerleri ile tümör sellülaritesi arasında anlamlı bir ilişki olduğu ortaya konmuştur. Bu çalışmada prospektif olarak DAG ile doku karakterizasyonu değerlendirmiştir. Çalışmada 30 hastada yüksek ve düşük b

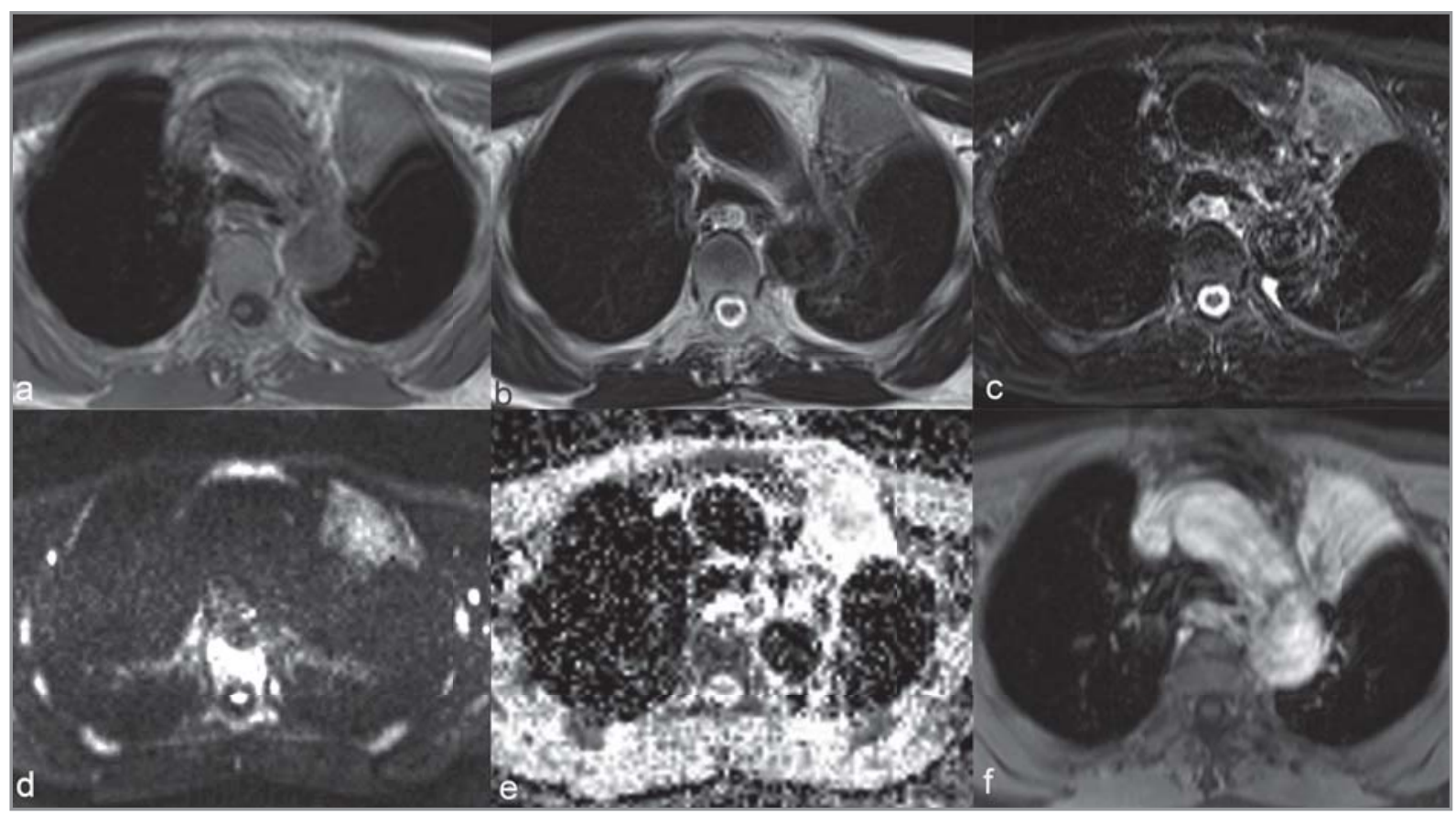

Resim 5. Yetmiş altı yaşında erkek hastada üst lobda benin bronş tıkanıklığına bağlı kollaps. (A) Aksiyel T1 ağırlıklı kesit, (B) Aksiyel T2 ağırlıklı kesit, (C) Aksiyel STIR kesiti, (D) Aksiyel b 1000, (E) Aksiyel ADC harita ve (F) Aksiyel T1 ağırlıklı kontrastlı kesitlerde sol akciğer üst lobun tamamında kollapsa ait T1, T2, STIR'da homojen intensite değişikliği, difüzyonda kısmi artış ve homojen belirgin kontrast tutulumu izlenmiştir. 


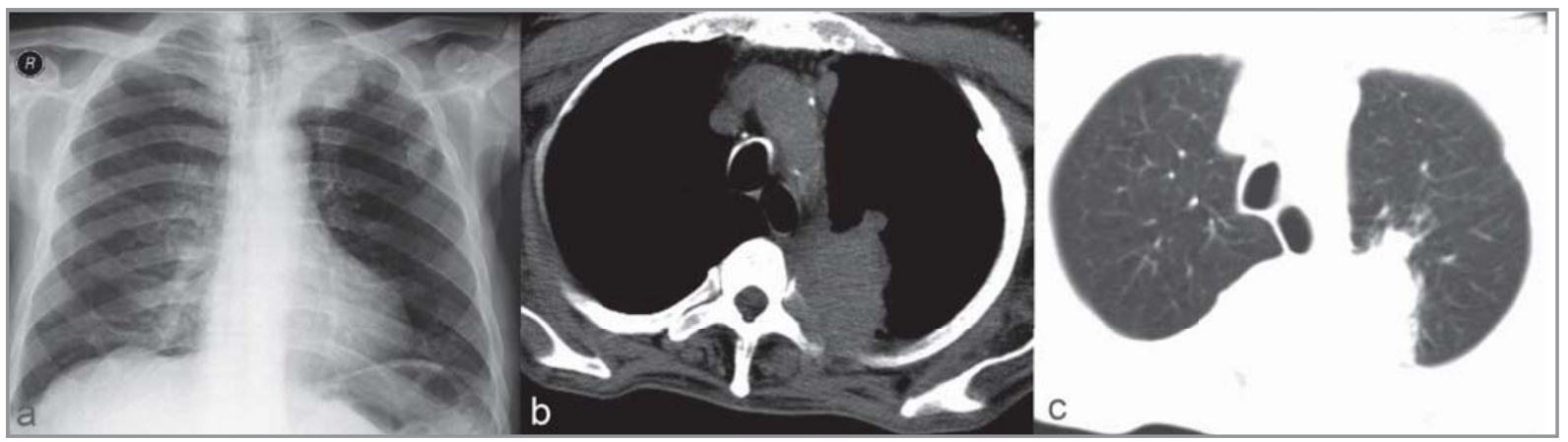

Resim 6. Yetmiş beş yaşında yassı hücreli kanser (Pancoast tümör) olan erkek hasta, (A) PA grafide sol akciğer apekste kitlesel lezyon izlenmektedir, (B) Biyopsi için alınan aksiyel kontrastsız BT'nin mediasten penceresinde sol akciğer üst lob apikoposterior segmentte gögüs duvarı uzanımı gösteren paramediastinal kitlesel lezyon izlenmektedir, (C) Biyopsi için alınan aksiyel kontrastsız BT’nin parankim penceresinde lezyonun spiküler kenar yapısı görülmektedir.

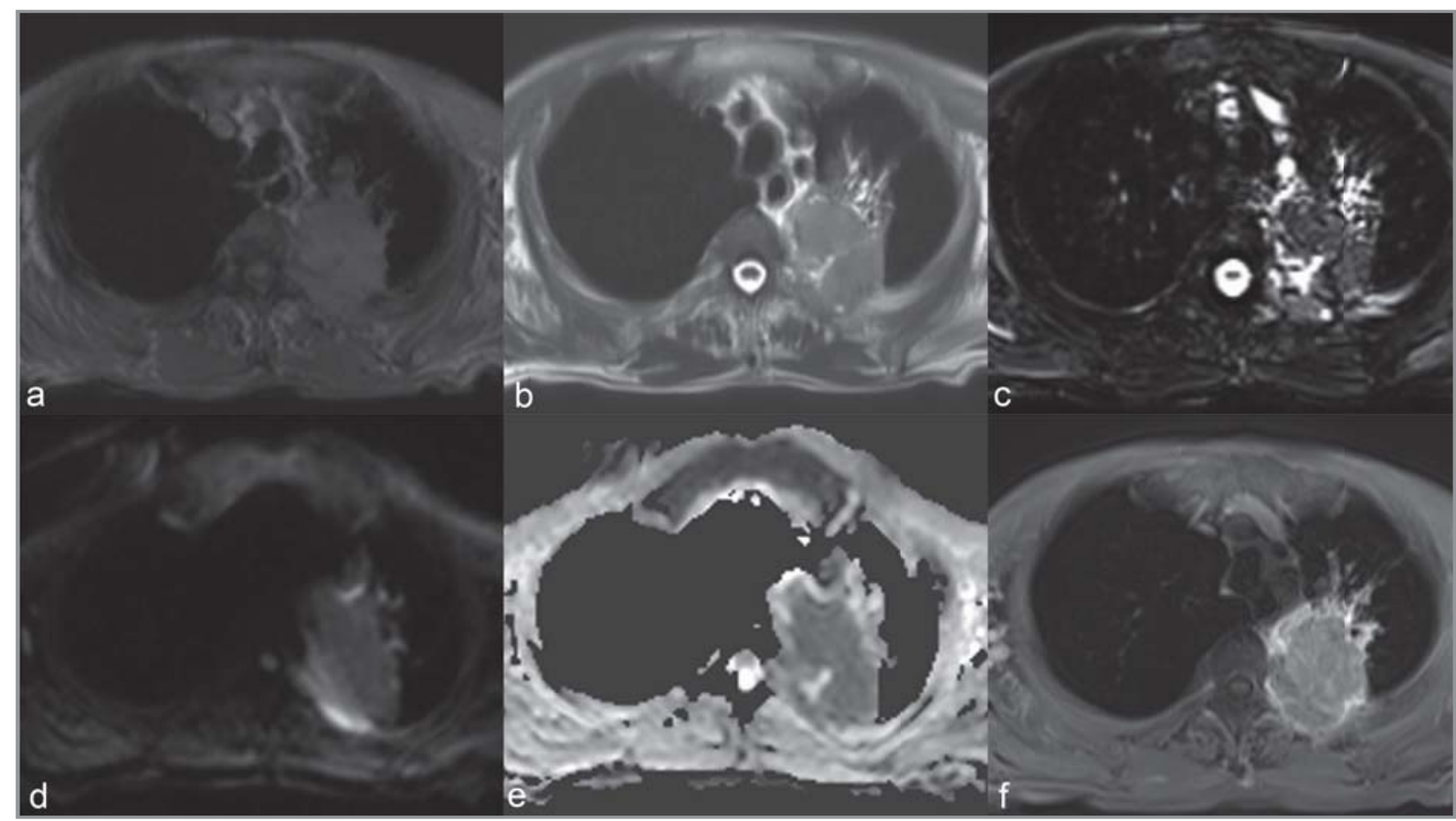

Resim 7. Yetmiş beş yaşında yassı hücreli kanser (Pancoast tümör) olan erkek hasta. (A) Aksiyel T1 ağırlıklı kesit, (B) Aksiyel T2 ağırlıklı kesit, (C) Aksiyel STIR kesiti, (D) Aksiyel b 1000, (E) Aksiyel ADC harita ve (F) Aksiyel T1 ağırlıklı kontrastlı kesitlerde heterojen intensitede, spiküler kenarlı, STIR'da hiperintens alanlar içeren, difüzyonda belirgin kısıtılık oluşturan, heterojen kontrast tutulumu gösteren kitle lezyon izlenmektedir.

değerleri kullanılarak ADC değerleri ölçülmüş, ADC değeri adenokarsinomda $2.12 \pm 0.60 \times 10^{-3} \mathrm{~mm}^{2} / \mathrm{sn}$, yassı hücreli karsinomda $1.63 \pm 0.50 \times 10^{-3} \mathrm{~mm}^{2} / \mathrm{sn}$ büyük hücreli kanserde $1.30 \pm 0.40 \times 10^{-3} \mathrm{~mm}^{2} / \mathrm{sn}$ ve küçük hücreli kanserde $2.09 \pm 0.30 \times 10^{-3} \mathrm{~mm}^{2} /$ sn bulunmuştur. Histopatolojik tipler arasında istatistiksel olarak anlamlı farklı ADC değerleri elde edilmiş olmasına rağmen birbiriyle örtüşen değerler de tespit edilmiştir.
DAG'daki değerler ile periferal akciğer adenokarsinomun histopatolojik tipleri arasında ilişki olduğunu gösteren başka bir çalışmada histopatolojik olarak bronkoalveoler kanser (BAC), ilerlemiş BAC, karışık subtip ve non-BAC olarak sınıflandırılan akciğer adenoklarsinomları değerlendirilmiştir (24). Bu karsinomlardan BAC prognoz bakımından iyi noninvaziv bir tümör olarak değerlendirilirken ilerlemiş BAC ve non-BAC alt-tipleri biyolojik olarak invaziv karsinom 


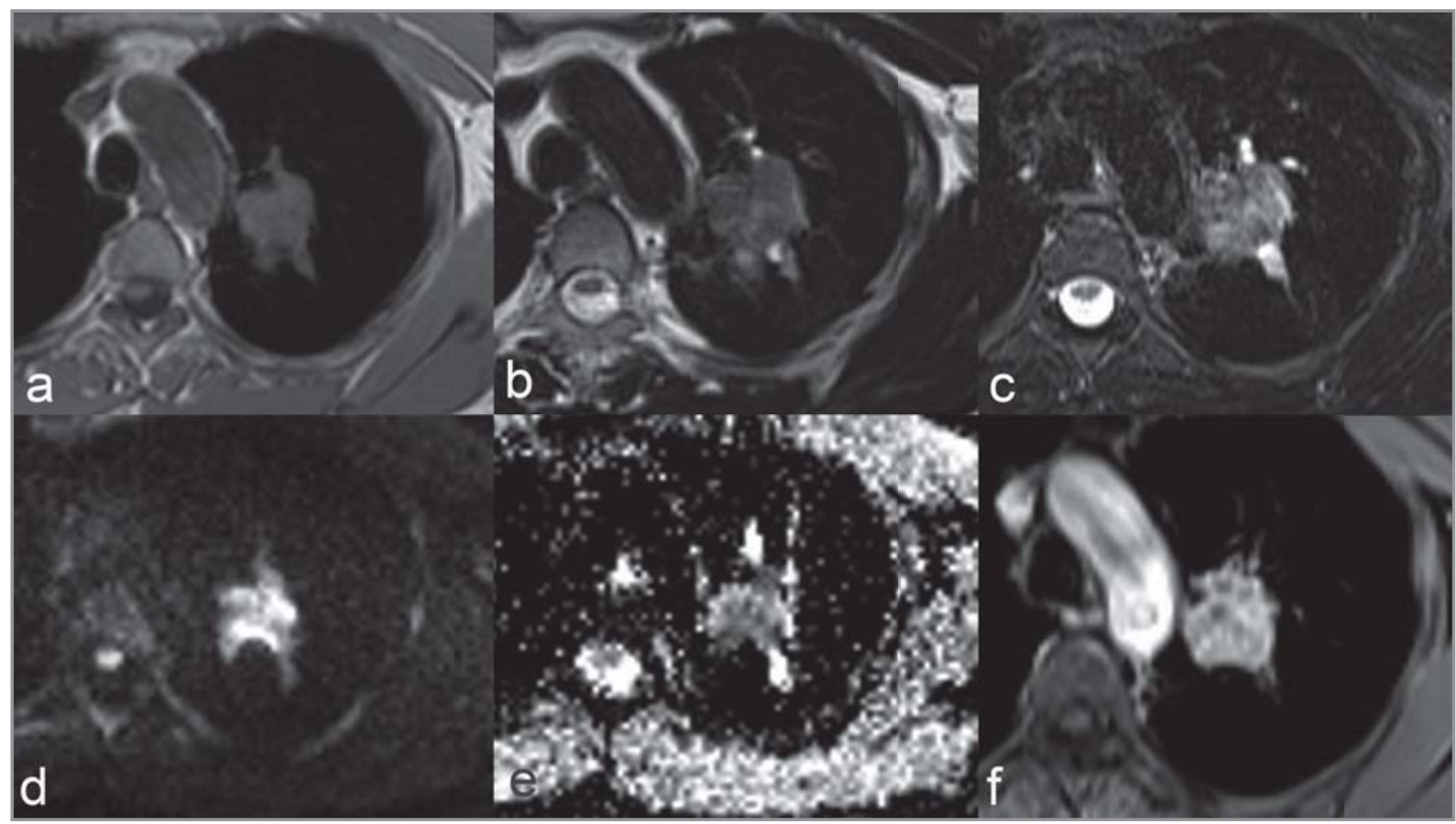

Resim 8. Kırk sekiz yaşında santral yassı hücreli kanser olan erkek hasta, (A) Aksiyel T1 ağırlıklı kesit, (B) Aksiyel T2 ağırlıklı kesit, (C) Aksiyel STIR kesiti, (D) Aksiyel b 1000, (E) Aksiyel ADC harita ve (F) Aksiyel T1 ağırlıklı kontrastlı kesitler 3 T MR ile alınmıştır. Sol akciğer üst lobta parahiler yerleşim gösteren, heterojen intensitede, spiküler kenarlı, STIR'da hiperintens alanlar içeren, difüzyonda belirgin kısıtlılık oluşturan, heterojen kontrast tutulumu gösteren kitle lezyon izlenmektedir. Lezyon çevresine ışınsal uzanan, T2 ve STIR'da hiperintens, kontrast tutmayan, difüzyonda artışa neden olan alanlar ise basıya bağlı gelişen bronş içi mukus plakları lehine değerlendirilmiştir.

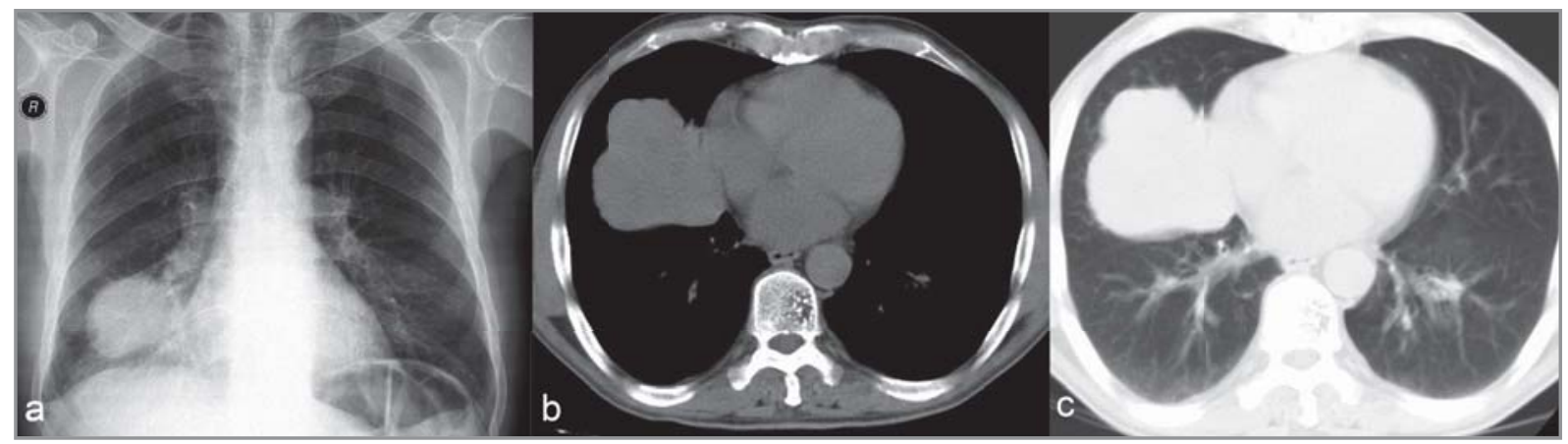

Resim 9. Altmış dört yaşında erkek hastada büyük hücreli kanser, (A) PA grafide sağ akciğer alt zonda kitlesel lezyon izlenmektedir, (B) Biyopsi için alınan aksiyel kontrastsız BT'nin mediasten penceresinde ve (C) Parankim penceresinde sağ akciğer orta lobda yerleşik lobüle kontürlü parakardiyak solid lezyon izlenmektedir.

olarak kabul edilmektedir. Bu çalışmada 47 hastada $3 \mathrm{~cm}$ veya daha küçük lezyonlarda cerrahi rezeksiyon veya histopatolojik örnekleme öncesi DAG görüntüleme yapılmıştır. Her tümör dört alt gruba ayrılmış, sinyal yok 1 , zayıf 2 , orta 3 , kuvvetli 4 olarak skorlanmıştır. DAG bulgularında orta ve güçlü sinyal intensiteleri ilerlemiş, BAC (\%79.2) ve nonBAC'da (\%88.9), BAC'a (\%95.2) göre istatistiksel olarak anlamlı şekilde fazla izlenmiştir. DAG ile güçlü sinyal intensitesi olanlar veya dinamik kontrastlı serilerde kuvvetli kontrast madde tutanların malin olduğuna karar verilmiştir. Duyarlılık \%97.0, özgüllük \%76.9 ve doğruluk oranı \%91.3 bulunmuştur. Ancak başka bir çalışmada 33 adenokarsinomlu hastada b 1000 değeri kullanarak DAG çalışmasında ADC değerlerinin adenokarsinomun subtiplerin ayrımında yararlı olmadığı söylenmektedir (13). DAG görüntülemede en önemli yalancı pozitif sebep oluş- 


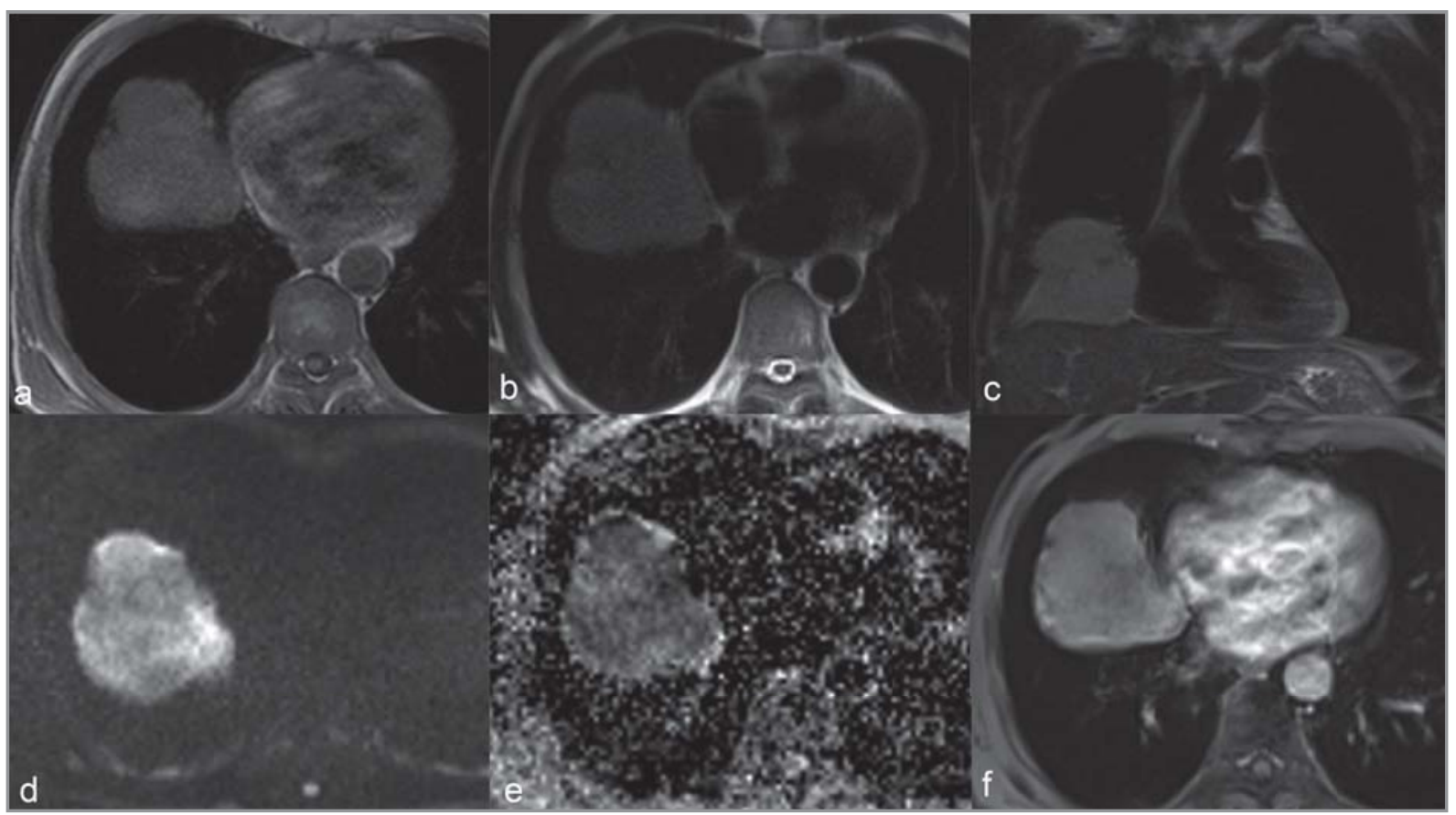

Resim 10. Altmış dört yaşında erkek hastada büyük hücreli kanser, (A) Aksiyel T1 ağırlıklı kesit, (B) Aksiyel T2 ağırlıklı kesit, (C) Koronal T2 kesiti, (D) Aksiyel b 1000, (E) Aksiyel ADC harita ve (F) Aksiyel T1 ağırlıklı kontrastlı kesitler 3 T MR ile alınmıştır. Sağ akciğer orta lobda kısmen homojen intensitede, lobüle kontürlü, difüzyonda belirgin kısıtlılık oluşturan, heterojen kontrast tutulumu gösteren kitle lezyon izlenmektedir.

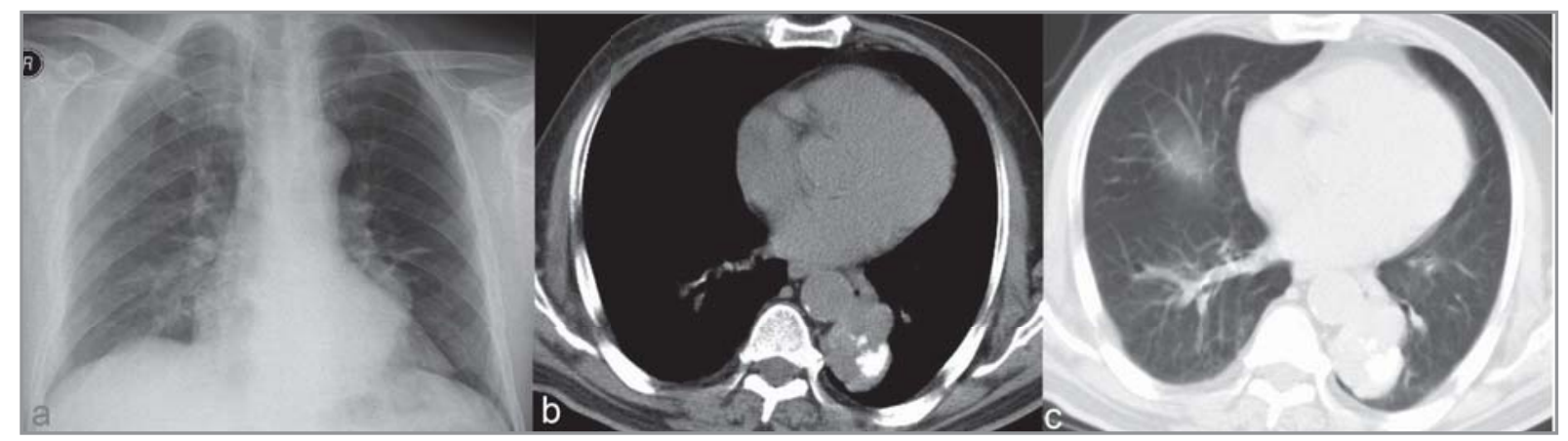

Resim 11. Altmış beş yaşında adenokarsinom tanısı alan erkek hasta, (A) PA grafide sol akciğerde retrokardiyak ve parahiler uzanım gösteren kitlesel lezyon izlenmektedir, (B) Biyopsi için alınan aksiyel kontrastsız BT'nin mediasten penceresinde sol akciğer alt lobda periferik amorf kalsifikasyon içeren lobüle kontürlü kitlesel lezyon izlenmektedir. Görünüm skar karsinomu düşündürmektedir, (C) Biyopsi için alınan aksiyel kontrastsız BT'nin parankim penceresinde lobüle kontürlü kitlesel lezyon izlenmektedir.

turan patolojiler tüberküloz veya diğer infektif orijinli granülasyon içeren lenf nodları ve konsolidasyonlardır (Resim 13, 14) (25).

Evre IA KHDAK hastalarında yapılan bir çalışmada DAG'ın tümör invazivliğinin değerlendirilmesindeki öngörüsü araştırılmıştır (9). Bu hastalarda cerrahiden önce PET/BT ve DAG çekimleri yapılmıştır. Tüm nodüller histopatolojik olarak değerlendirilmiştir. Nodal, lenfovasküler veya plevral invazyon varlığı invaziv akciğer kanseri olarak kabul edilmiş, bu bulguların varlığına göre tümörler invaziv ve noninvaziv olarak sınıflandırılmıştır. Difüzyon ağırlıklı görüntülemenin evre IA KHDAK'larda invazivliğinin değerlendirilmesinde bağımsız bir prediktif faktör olarak kullanılabileceği söylenmektedir. Bununla birlikte evre IA olgularının \%20'sinde lenf nodu metastazı saptandığından prognozları hala kötü olarak değerlendirilmektedir. DAG kullanılarak yapılan sınıflama sisteminin invaziv karsinomu tespit etmede duyarlılı- 


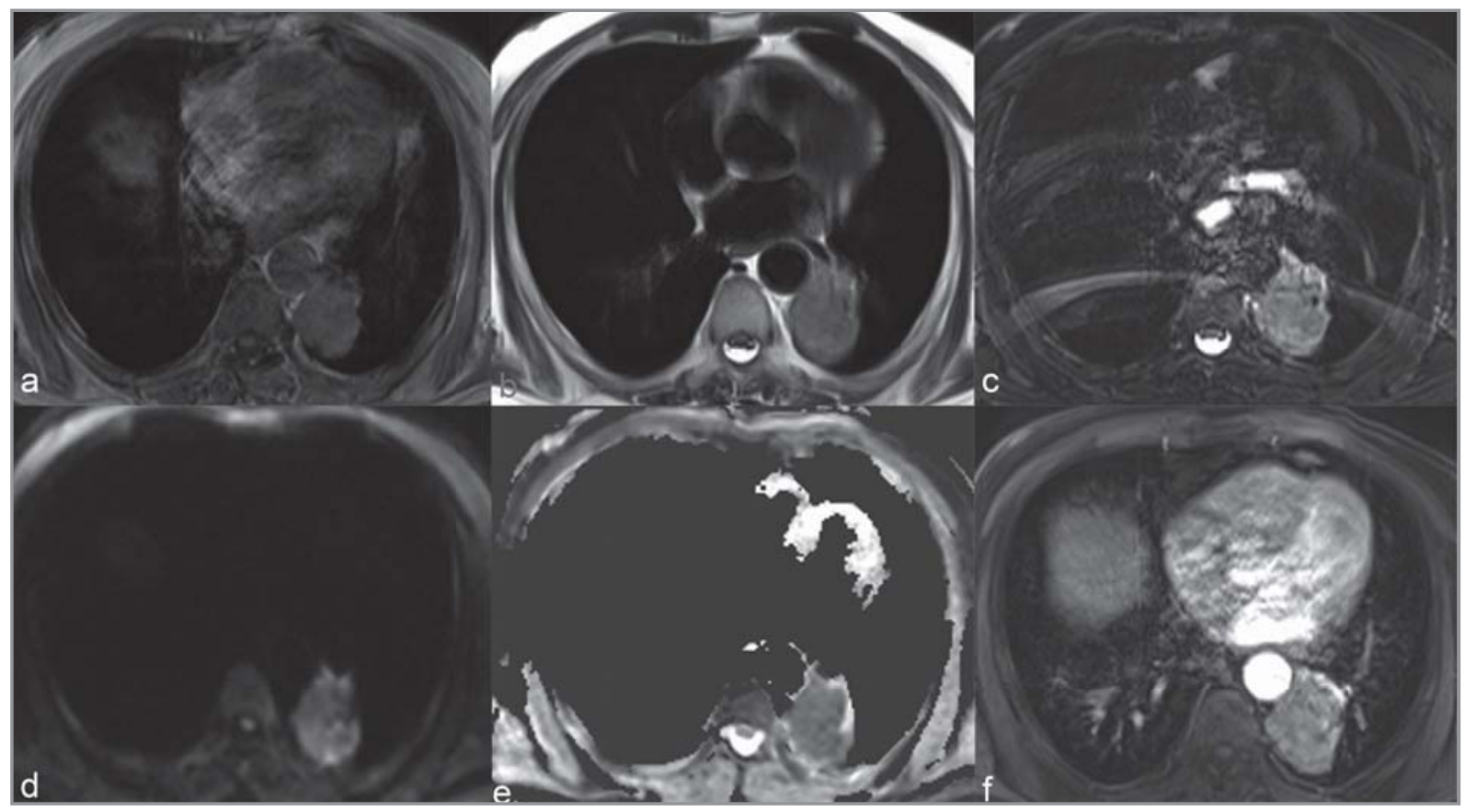

Resim 12. Altmış beş yaşında adenokarsinom tanısı alan erkek hasta, (A) Aksiyel T1 ağırlıklı kesit, (B) Aksiyel T2 ağırlıklı kesit, (C) Koronal STIR kesiti, (D) Aksiyel b 800, (E) Aksiyel ADC harita ve (F) Aksiyel T1 ağırlıklı kontrastlı kesitler 3 T MR cihazında elde olmuştur. Görüntülerde hafif heterojen intensitede, STIR'da kısmen parlayan, difüzyonda kısıtıılık oluşturan ve heterojen kontrast tutulumu gösteren kitle lezyon izlenmektedir.

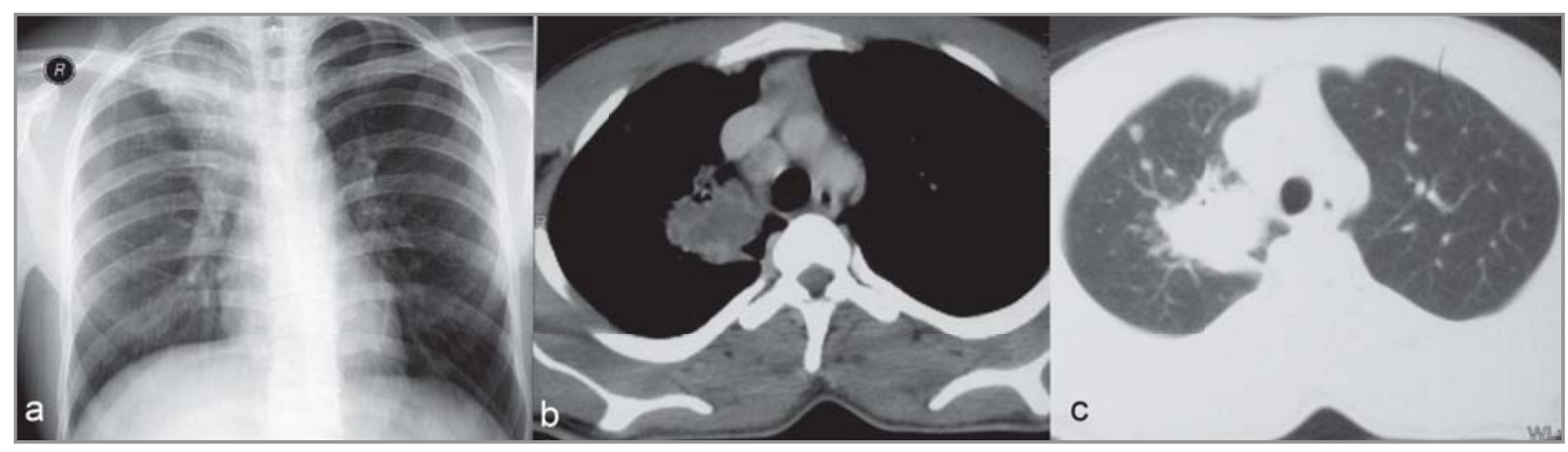

Resim 13. Yirmi yaşında tüberküloz granülom ve LAP tanısı alan erkek hasta, (A) PA grafide sağ akciğer apekste konsolidasyon izlenmektedir, (B) Aksiyel kontrastlı BT'de mediasten penceresinde düzensiz kenarlı ve paratrakeal LAP içeren görünüm izlenmektedir. Lezyonda ve lenf nodunda halkasal kontrast tutulumları mevcuttur, (C) Aksiyel kontrastlı BT'de parankim penceresinde konsolidasyona satellit nodüllerin eşlik ettiği görülmektedir.

ğı \%90, özgüllüğü \%81, pozitif prediktif değeri \%60 ve negatif prediktif değeri \%96 olarak bulunmuştur. Operasyon öncesi hastalarda invaziv tümör varlığının tespiti cerrahi kararını ve tedavi protokolünü değiştirebileceği belirtilmiştir.

Başka bir çalışmada ise 96 KHDAK ve 28 benin lezyonu bulunan hastalarda PET/BT ve DAG bulguları karşılaştırılmıştır (25). Evre IA, IB ve diğer ileri evrelerde PET/BT ile Flor18 ile işaretli deoksi glukoz
(FDG) tutulumunun istatistiksel olarak anlamlı olduğunu ancak DAG'da ADC değerlerinde anlamlı fark olmadığını bulmuşlardır. DAG sadece KHDAK ve benin nodüllerin ayırımında PET/BT ile benzer davranış göstermektedir.

Postobstrüktif pnömoni-tümöral lezyon ayırımı: Santral akciğer kanserlerinde direkt veya dolaylı basıya bağlı olarak postobstrüktif pnömoni veya periferal akciğer kollapsı oluşabilir. Bu durumda santral tümör 


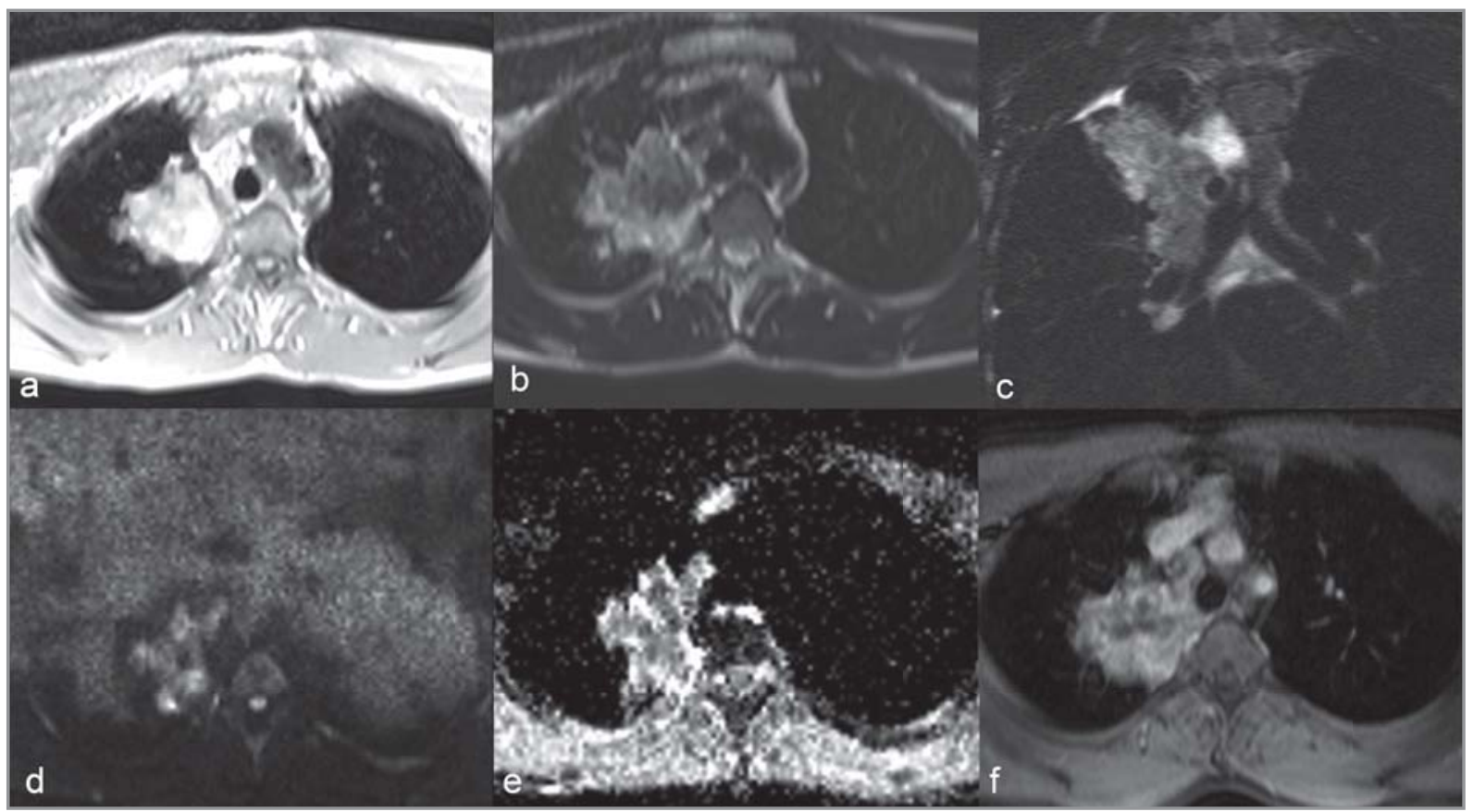

Resim 14. Yirmi yaşında tüberküloz granülom ve LAP tanısı alan erkek hasta, (A) Aksiyel T1 ağılıklı kesit, (B) Aksiyel T2 ağırlıklı kesit, (C) Koronal STIR kesiti, (D) Aksiyel b 800, (E) Aksiyel ADC harita ve (F) Aksiyel T1 ağırlıklı kontrastlı kesitlerde heterojen intensitede kitle benzeri görünüm oluşturan, difüzyonda yanıltıcı olarak kısıtlılığa neden olan, heterojen kısmen halkasal kontrast tutulumu gösteren lezyon izlenmektedir. LAP'ta benzer özellikler taşımaktadır. STIR sekansında minimal loküle plevral mayiide izlenmektedir. (Difüzyon MRG'nin yalancı pozitif olduğu durumlara örnektir.)

ile etrafındaki konsolide alanın ayrımı zorlaşır. Tümör boyutu hastaya ait tüm tedavi süreçlerinde en hayati komponentlerden biri olup doğru ölçülmesi gereklidir. Bu ayırımı yapabilmek için DAG kullanımının araştırıldığı, 27 hastanın yer aldığı, b 0 ve b 1000 değerleri kullanılan bir çalışmada hem postobstrüktif alanlardan hem de tümöral lezyondan ADC değerleri hesaplanmıştır (26). Bu değerler arasında istatistiksel olarak anlamlı fark bulunmuştur. Santral akciğer kanserlerinin evrelenmesinde DAG görüntülemenin yararlı olduğunu göstermişlerdir.

Akciğer kanseri ve buna sekonder kollapsı bulunan 33 olguda IV kontrast madde sonrası çekilen BT ile DAG sonuçları karşılaştırılmış, bu hastalarda kontrastlı BT ile 14 hastada, T2 görüntülerde 21 hastada kollabe akciğer ile tümör ayırımı yapılabilirken DAG ile 26 hastada yapılabilmiştir. Sekiz olguda T2 görüntüler ile ayırt edilmesi mümkün olmayan lezyonlar DAG ile ayırt edilebilir hale gelmiştir. Bu çalışmada sonuç olarak DAG ile T2 görüntüleri birlikte kullanmanın \%88 (29/33) oranda kollabe akciğer ile tümör ayırımını yapabildiğini göstermiş ve kontrastlı $\mathrm{BT}^{\prime}$ den daha iyi sonuçlar elde edildiği saptanmıştır (27).
Kemoterapi sonrası cevabın değerlendirilmesi: Kemoterapi sonrası tümörün tedaviye cevabının erken dönemde bilinmesi kemoterapiye yön vermede yararlı olup hastanın surveyine katkı sağlayabilmektedir. Yakın zamanda yapılan bir çalışmada KHDAK hastalarda kemoterapi sonrası cevabın değerlendirilmesinde evre 3B ve evre 4 KHDAK tanıI 28 hasta kemoterapi öncesi ve sonrasında, dinamik kontrastlı MRG ve DAG ile değerlendirilmiştir (28). DAG görüntüler için 1,5 T MR cihazı ile kemoterapiden 1 hafta önce ve 3-4 hafta sonra değerlendirmeler yapılmıştır. Hareket artefaktlarını azaltmak amacıyla kardiyak ve solunumsal tetikleme kullanılmıştır. Difüzyon değerler olarak b 0 ve b 1000 olarak alınmıştır. Çalışmada tümör boyutlarındaki azalma ile ADC değerindeki değişiklik karşılaştırılmış olup erken dönem ADC değişikliğiyle tümör boyutundaki azalmanın istatistiksel olarak uyumlu olduğu tespit edilmiştir. Bu çalışma özellikle tümörün erken dönemde boyutsal ve hemodinamisinde değişiklik başlamadan önce ADC değerlerinde değişikliğin olduğu görülmektedir. Erken dönem tedaviye cevabın değerlendirilmesi açısından olumlu sonuçlar içermektedir. 
Kemoterapiye cevabın değerlendirilmesinde $D A G^{\prime}$ । araştıran başka bir çalışmada ise; 19 hastada kemoterapiden 1 hafta önce ve 1 ay sonra konvansiyonel $M R$ ve DAG kullanmışlar, $A D C$ değerleri ile tümörün kısa, uzun aksı ve ortalama uzunluğunu karşılaştırmışlar (29). ADC değerleri ile uzun aks arası negatif korelasyon bulunmuştur. ADC değerlerindeki değişiklik ile kısa-uzun aksı ve ortalama uzunluğu arasında pozitif korelasyon bulunmuştur. ADC değerlerindeki değişikliğin erken dönem cevabın değerlendirilmesinde hassas olduğu ve morfolojik bulgularla birlikte kemoterapinin dinamik monitörizasyonunda kullanılabileceği söylenmiştir (29).

Tümör $\mathbf{M}$ evrelemesi: Prospektif olarak yapılan bir çalışmada 203 KHDAK'lı hastada $M$ evreleme için DAG içeren ve içermeyen tüm vücut MR tetkiki PET/ BT ile birlikte karşılaştırılmış, DAG içeren tüm vücut $M R$ incelemenin tümörün $M$ evrelemesinde $\mathrm{PET} / \mathrm{BT}$ kadar doğruluğa sahip olduğu gösterilmiştir (21).

Yine bu konu ile ilgili yapılan diğer bir çalışmada ise $115 \mathrm{KHDAK}^{\prime} \mathrm{l}_{\text {ı hastada prospektif olarak M evreleme }}$ için DAG içeren ve içermeyen tüm vücut MR tetkiki, PET/BT ve kemik sintigrafi kullanılmıştır (30). Belirli eşik değerleri uygulandığında DAG'lı tüm vücut $M R^{\prime} ı$ özgüllük ve doğruluk oranı, sintigrafi ve PET/ BT'den anlamlı olarak yüksek bulunmuştur. Çalışmaya göre DAG'ın, KHDAK'lı hastalarda kemik metastazının saptanmasında sintigrafi ve/veya PET/BT kadar doğru değerlendirilebileceği söylenmektedir.

\section{Mediastinal Lezyonlar}

Mediastinal lenf nodu: KHDAK'lı hastalarda lenf nodu evrelemesi önemlidir. Akciğer kanseri şüphesi olan hastalarda BT inceleme temel görüntüleme yöntemi olmakla birlikte lenf nodu tutulumunu göstermede duyarlıık ve özgüllüğü sadece boyut kriteri kullandığı için kısıtlıdır. Son yıllarda PET/BT’nin kullanıma girmesi ile $1 \mathrm{~cm}$ 'den daha küçük boyuttaki lenf nodları bile yüksek duyarlılıkta saptanmaya başlanmıştır (31). PET/BT'nin bilinen en önemli dezavantajı eşlik eden inflamatuvar lenfadenitli hastalarda büyük bir oranda ortaya çıkan yanlış pozitif sonuçlardır (32). Mediastinal lenf nodlarında da difüzyon MRG çalışmaları umut verici sonuçlar vermektedir.

KHDAK'lı hastalarda DAG'ın etkinliğini araştıran bir çalışmada operasyon öncesinde 42 hastada nefes tutmadan STIR-EPI sekans ile tespit edilen lenf nodla$\mathrm{rl}$, operasyon sonrası rezeke edilen lenf nodları ile karşılaştırılmıştır (10). MR'da lenf nodu metastazı, boyutundan bağımsız olarak bir lenf nodu lokalizasyonunda benzer T2 ağırlıklı görüntüde izlenen hipointens odak olarak tanımlanmıştır. Bu çalışmada DAG, histopatolojik olarak kanıtlanmış her 5 lenf nodundan 4 (\%80)'ünü tespit etmiş ve mediastinal lenf nodu metastazı olmayan 37 hastadan 36 $(\% 97)^{\prime}$ sını ayırt edebilmiştir. Yani DAG yüksek negatif prediktif değere sahiptir. Özellikle KHDAK'larda mediastinal lenf nodu değerlendirilmesinde alternatif noninvazif bir teknik olarak kullanılabilir. Böylece PET ve mediastinoskopi ihtiyacını azaltabilir (Resim 15-18).

Daha güncel bir çalışmada ise, toraks BT sonucunda akciğer kanserinden şüphelenilen 35 hastada 95 lenf nodu (8'i KHDAK, 10'u küçük hücreli kanser, 50'si sarkoidoz, 14 'ü reaktif lenf nodu ve $8^{\prime} i$ ise nekrotizan granülomatöz lenfadenit) benin malin ayırımı için kantitatif ADC değerleri kullanarak mediastinoskopi veya cerrahi sonuçlar ile karşılaştırılmıştır (4). Bu çalışmada benin lenf nodları ile karşılaştırıldıklarında malin lenf nodlarının belirgin olarak daha düşük ADC değerlerine sahip oldukları gösterilmiştir.

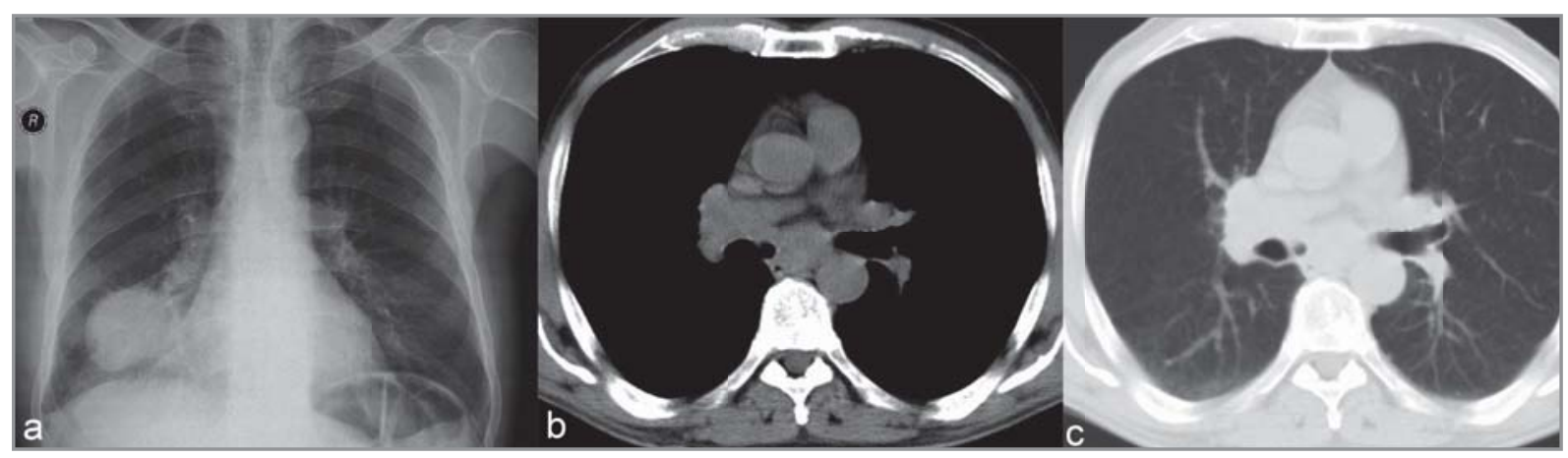

Resim 15. Altmış dört yaşında erkek hastada büyük hücreli kanser (Resim 9, 10 no'lu olgu), (A) PA grafide sağ akciğer alt zonda kitlesel lezyon izlenmektedir, (B) Biyopsi için alınan aksiyel kontrastsız BT'nin mediasten penceresinde ve (C) Parankim penceresinde subkarinal ve sağ hiler alanda LAP izlenmektedir. 


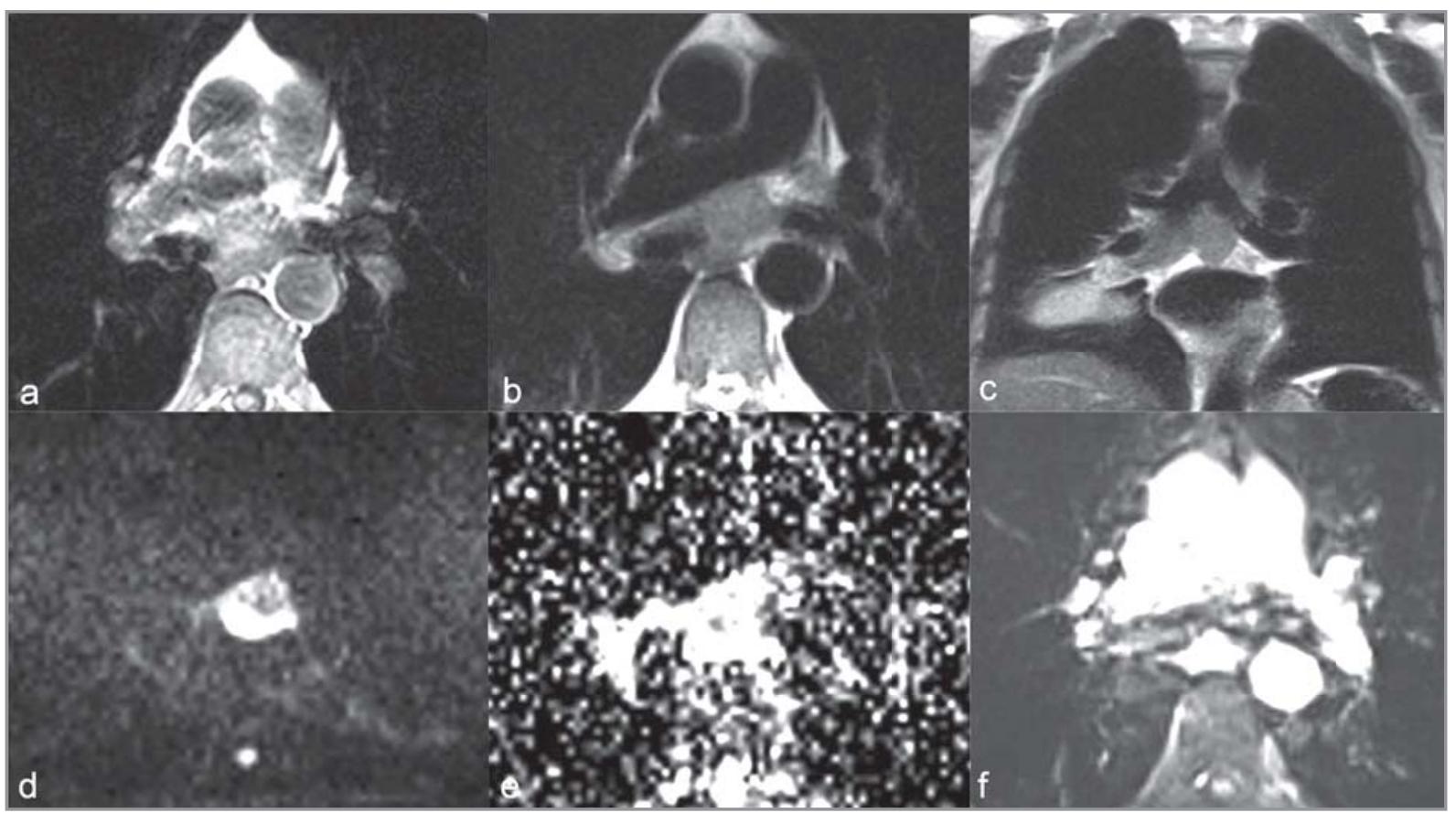

Resim 16. Altmış dört yaşında erkek hastada büyük hücreli kanser (Resim 9, 10 no'lu olgu), (A) Aksiyel T1 ağırlıklı kesit, (B) Aksiyel T2 ağırıılı kesit, (C) Koronal T2 kesiti, (D) Aksiyel b 1000, (E) Aksiyel ADC harita ve (F) Aksiyel T1 ağırlıklı kontrastlı kesitler 3 T MR ile alınmıştır. Subkarinal ve sağ hiler alanda izlenen LAP'larda difüzyonda kısıtlılık ve kontrast tutulumu izlenmektedir.

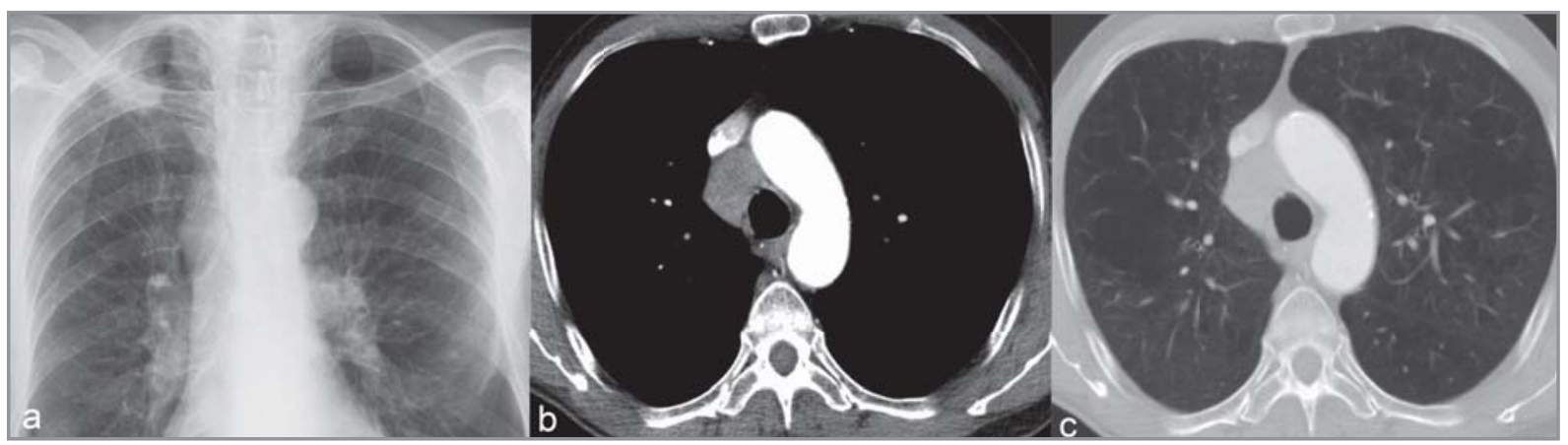

Resim 17. Yetmiş yedi yaşında yassı hücreli kanser olan erkek hasta (Resim 3,4 no'lu olgu), (A) PA grafide sağ akciğer üst lob apikal segmentte nodüler lezyon ve sağ paratrakeal çizgide kalınlaşma ve opasite artımı mevcuttur, (B) Aksiyel kontrastlı BT'de mediasten penceresinde ve (C) Parankim penceresinde să̆ paratrakeal LAP görülmektedir.

Başka bir çalışmada ise DAG ve PET/BT'nin KHDAK'lı hastaların $\mathrm{N}$ evrelemesinde doğruluk oranları karşılaştırılmıştır (33). Bu çerçevede 88 hastaya operasyon öncesi hem DAG hem de PET/BT yapılmış ve çıkarılan lenf nodları histopatolojik olarak Naruke haritalaması ile analiz edilmiştir. DAG, 1.5 T MR ile yüksek b değerinin kullanıldığı $\left(1000 \mathrm{~mm}^{2} / \mathrm{s}\right)$ ekoplanar görüntüleme sekansında gerçekleştirilmiştir. Toplam 734 lenf nodu analiz edilmiş ve histopatolojik inceleme sonucu bu lenf nodlarından 36'sının metastatik, 698'inin metastatik olmadığı bulunmuştur. Metastatik lenf nodu tespitinde DAG ile PET/BT arasında kayda değer bir farklılık izlenmemiştir. Metastatik olmayan lenf nodlarını tespitinde ise DAG'ın, PET/BT'ye göre, daha düşük yanlış pozitif oranına sahip olduğu bildirilmiştir. ilginç olarak DAG'daki yanlış pozitif sonuçların tamamının tüberküloz ve diğer nedenlere bağ|ı granülomlardan kaynaklandığı histopatolojik olarak gösterilmiştir.

Akciğer kanserli hastalarda yapılan bir çalışmada difüzyon MRG ile PET/BT lenf nodu evrelendirmesin- 


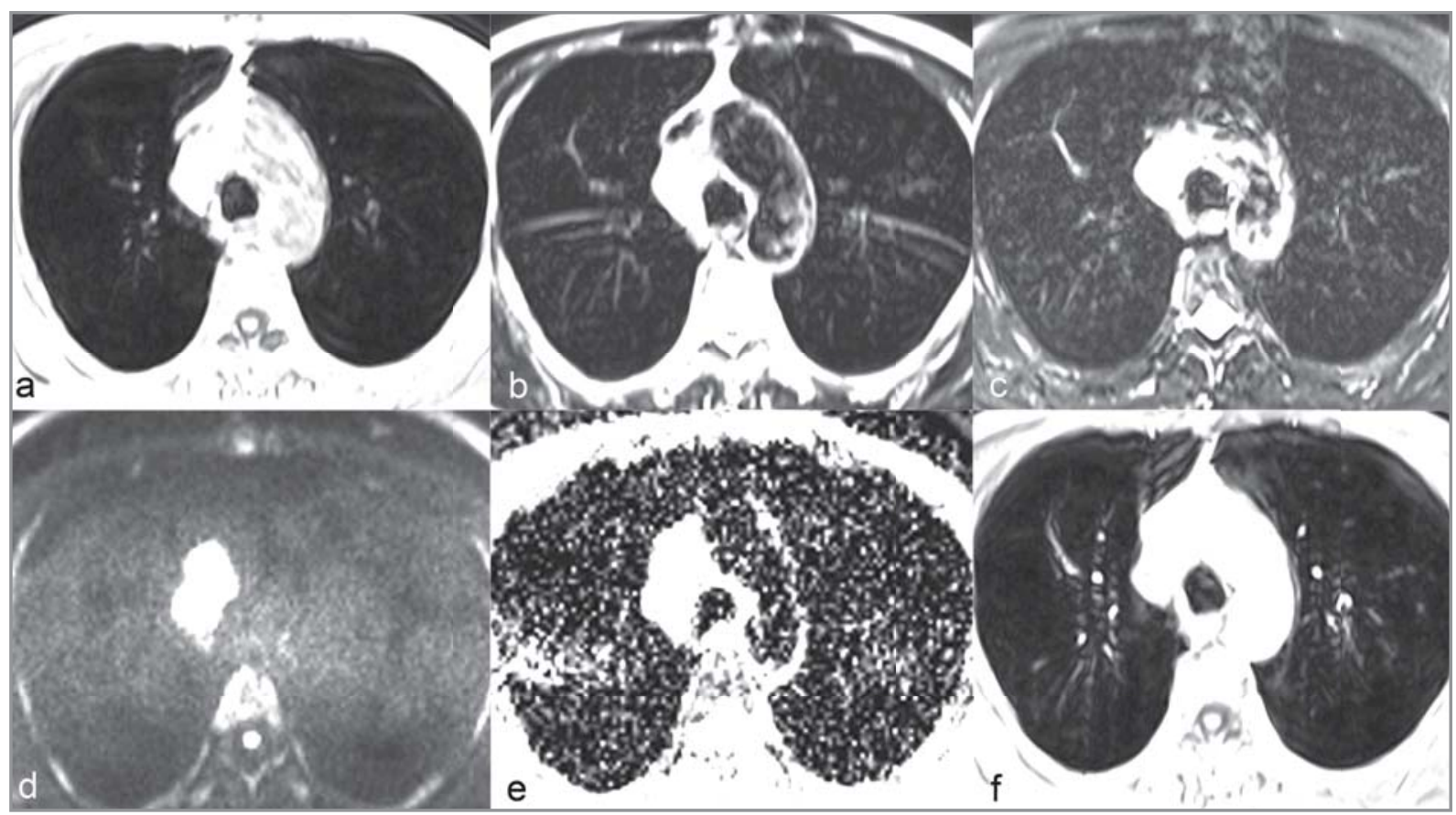

Resim 18. Yetmiş yedi yaşında yassı hücreli kanser olan erkek hasta (Resim 3, 4 no'lu olgu), (A) Aksiyel T1 ağırlıklı kesit, (B) Aksiyel T2 ağırlıklı kesit, (C) Aksiyel STIR kesiti, (D) Aksiyel b 1000, (E) Aksiyel ADC harita ve (F) Aksiyel T1 ağırlıklı kontrastlı kesitler 3 T MR ile alınmıştır. Sağ paratrakeal alanda izlenen LAP'da difüzyonda kısıtlılık ve kontrast tutulumu izlenmektedir.

de karşılaştırılmış olup, 20 hastalık seride difüzyon MR, PET/BT'ye göre 1 hastada ileri, 4 hastada düşük, 15 hastada ise olması gereken $\mathrm{N}$ evresi bulunmuştur (34). ileri evre olarak belirlenen hastada supraklaviküler 4-7 mm ebatlı lenf nodu saptanmıştır. Düşük evre olarak saptanan hastaların üçünde lenf nodları MR ve DAG ile görülememiştir. Bir hastada ise konvansiyonel MR ile saptanan lenf nodu DAG ve PET/ BT ile saptanamamıştır. Sonuç olarak DAG'ın küçük lenf nodu tespitinde her ne kadar faydalı olsa da konvansiyonel MR'a göre avantajlı olmadığı fikrine varılmıştır. Konvansiyonel $M R^{\prime} ı$ tek başına veya DAG ile birlikte kullanıldığında PET/BT'ye benzer sonuçlar elde edildiği gösterilmiştir.

Bir çalışmada KHDAK olan 250 hastada STIR, DAG ve PET bulguları karşılaştırılmıştır (35). STIR'da lenf nodu/serum fizyolojik ve lenf nodu/kas oranları, $D A G$ 'da ADC değeri ve PET'te ise SUV değerleri elde edilmiştir. Incelemeler hem kantitatif hem de kalitatif olarak yapılmıştır. STIR'da lenf nodu/serum fizyolojik ve lenf nodu/kas oranlarında duyarlılık \%82.8 ve doğruluk \%86.8 olup ADC'de ise sırasıyla \%74.2 ve $\% 84.4$ bulunmuştur. STIR sekansı sonuçları hem DAG ve hem de PET'ten daha hassas ve doğru olduğu söylenmektedir.
Mediastinal kitle lezyonlar: Mediastinal kitlelere yönelik yapılan bir çalışmada; tipik tiroid kitlesi ve vasküler lezyonlar çalışma dışı tutulup, diğer kitlesel patolojiler değerlendirilmiştir (36). Boyutlarının 15 mm'nin üstünde olduğu 53 histopatolojik veya klinik olarak tanısı konmuş lezyonda benin malin ayırımında kantitatif ADC değerleri kullanılarak karşılaştırma yapılmıştır. 3 T MR cihazı kullanılan çalışmada hareket artefaktlarını azaltmak için nefes tutmalı ve kardiyak tetiklemeli sekans uygulanmış ve rutin $M R$ sekansları ve DAG görüntüler (b 0 ve b 1000) elde edilmiştir. Elde edilen sonuçlara göre benin lezyonlar ile malin lezyonlar arasında istatistiksel anlamlı farklılık saptanmıştır. Malin lezyonlarda ADC değeri daha düşük ölçülmesine rağmen adenokarsinomlu bir hastada yüksek ADC değerleri saptanmıştır. Bu olguda nekrotik alanlar mevcut olduğundan ADC değerleri yüksek olarak ölçülmüştür. Çalışmadaki mevcut verilere göre DAG'ın benin-malin ayırımında duyarlııı̆ı \%95 ve özgüllüğü \%87 olarak değerlendirilmiştir.

"Single-shot echo-planar" MR sekansı ile elde edilen DAG görüntüleme ile mediastinal tümörlerin değerlendirildiği bir çalışmada ADC değerleri histopatolojik bulgularla karşılaştırılmıştır (37). Malin mediastinal tümörlerde $1.09 \pm 0.25 \times 10^{-3} \mathrm{~mm}^{2} / \mathrm{sn}$ ve benin 
tümörlerde $2.38 \pm 0.56 \times 10^{-3} \mathrm{~mm}^{2} / \mathrm{sn}$ bulunmuştur. ADC'de eşik değeri 1.56 alındığında duyarlılık \%95, özgüllük \%94, pozitif prediktif değer \%94 ve negatif prediktif değer ise $\% 96$ bulunmuştur.

Yirmi dört çocuk hastada mediastinal lezyonların değerlendirildiği çalışmada malin lezyonlarda ADC değerleri $0.91 \pm 0.17 \times 10^{-3} \mathrm{~mm}^{2} / \mathrm{sn}$ ve benin olanlarda ise $1.8 \pm 0.33 \times 10^{-3} \mathrm{~mm}^{2} / \mathrm{sn}$ bulunmuştur (38). ADC'de eşik değeri 1.2 alındığında duyarıılık \%92, özgüllük \%94, pozitif prediktif değer \%94 ve negatif prediktif değer ise $\% 92$ bulunmuştur.

Her üç çalışmaya göre de mediastinal lezyonlarda difüzyon MRG tek başına değerli bilgiler vermektedir. Tüm vücut DAG ile birlikte yapılan MR çalışmalarında, DAG sonuçları lenfoma evrelemesinde BT veya $\mathrm{PET} / \mathrm{BT}^{\prime}$ ye eşdeğer bulunmuştur (36-38).

\section{SONUÇ}

Difüzyon MRG ile yapılan çalışmalar, özellikle nodül ve kitle gibi tümöral patolojilerde yoğunlaşmış olup, benin malin ayrımına önemli katkı sağlamaktadır. Akciğer kanserlerinde ise DAG'ın TNM sınıflamasında; T evresinde, tümörün gerçek çapının hesaplanmasında, tümörün atelektazi, kollaps, postobstrüktif değişiklikten ayrılmasında ve kemoterapiye erken cevabın değerlendirilmesinde ilave önemli bilgiler verdiği görülmektedir. $N$ ve $M$ değerlendirmede ise diğer modalitelere benzer sonuçlar gösterdiği bildirilmektedir. Plevral, mediastinal ve kardiyak patolojilerde de katkı sağlayabileceğine dair çalışmalar mevcuttur ancak bu alanlarda daha geniş serilere ihtiyaç olduğunu düşünmekteyiz. Ayrıca, toraksta difüzyon MRG çoğu çalışmada tekil incelenmiş olup özellikle konvansiyonel MR sekansları, dinamik kontrastlı MR ve STIR sekansı gibi diğer sekanslar ile birlikte çoklu değerlendirmeye ihtiyaç olduğu görülmektedir. Bu sayede DAG'la birlikte MR inceleme, toraks patolojilerindeki algoritmada hak ettiği noktaya varacaktır.

\section{ÇIKAR ÇATIŞMASI}

Bildirilmemiştir.

\section{KAYNAKLAR}

1. Eisenberg RL; Fleischner Society. Ways to improve radiologists' adherence to Fleischner Society guidelines for management of pulmonary nodules. I Am Coll Radiol 2013;10:439-41.

2. Lacson $R$, Prevedello $L M$, Andriole $K P$, Gill $R$, LenociEdwards J, Roy C, et al; Fleischner Society. Factors associated with radiologists' adherence to Fleischner Society guidelines for management of pulmonary nodules. I Am Coll Radiol 2012;9:468-73.
3. Matoba M, Tonami H, Kondou T, Yokota H, Higashi K, Toga $H$, et al. Lung carcinoma: diffusion-weighted $\mathrm{mr}$ imaging--preliminary evaluation with apparent diffusion coefficient. Radiology 2007;243:570-7.

4. Koşucu P, Tekinbaş C, Erol M, Sari A, Kavgaci H, Oztuna $F$, et al. Mediastinal lymph nodes: assessment with diffusion-weighted MR imaging. I Magn Reson Imaging 2009;30:292-7.

5. Razek AA, Elmorsy A, Elshafey M, Elhadedy $T$, Hamza O. Assessment of mediastinal tumors with diffusion-weighted single-shot echo-planar MRI. I Magn Reson Imaging 2009;30:535-40.

6. Modesti G, Zimmermann B, Börsch M, Herrmann A, Saalwächter K. Diffusion in Model Networks as Studied by NMR and Fluorescence Correlation Spectroscopy. Macromolecules 2009;42:4681-9.

7. Gillard JH, Waldman AD, Barker PB. Clinical MR Neuroimaging Diffusion, Perfusion and Spectroscopy. In: Jones, D.K. ed, Fundamentals of diffusion MR imaging, Cambridge: Cambridge Univ. Pres., 2005:54-86.

8. Biederer J, Beer M, Hirsch W, Wild I, Fabel M, Puderbach $M$, et al. MRI of the lung (2/3). Why ... when ... how? Insights Imaging 2012;3:355-71.

9. Kanauchi N, Oizumi H, Honma T, Kato H, Endo M, Suzuki J, et al. M. Role of diffusion-weighted magnetic resonance imaging for predicting of tumor invasiveness for clinical stage IA non-small cell lung cancer. Eur I Cardiothorac Surg 2009;35:706-10.

10. Hasegawa I, Boiselle PM, Kuwabara K, Sawafuji M, Sugiura $H$. Mediastinal lymph nodes in patients with non-small cell lung cancer: preliminary experience with diffusion-weighted MR imaging. J Thorac Imaging 2008;23:157-61.

11. Kahraman M. Plevral patolojisi olan hastalarda difüzyon manyetik rezonans incelemenin benign malign ayrımında yeri ve önemi (tez). Erzurum: Atatürk Üniversitesi Tıp Fakültesi; 2012.

12. Satoh S, Kitazume Y, Ohdama S, Kimula Y, Taura S, Endo $Y$. Can malignant andbenign pulmonary nodules be differentiated with diffusion-weighted MRI? AJR Am I Roentgenol. 2008; 191:464-70.

13. Koyama H, Ohno Y, Kono A, Takenaka D, Maniwa $Y$, Nishimura $Y$, et al. Quantitative and qualitative assessment of non-contrast-enhanced pulmonary MR imaging for management of pulmonary nodules in 161 subjects. Eur Radiol 2008; 18:2120-31.

14. Frericks BB, Meyer BC, Martus $P$, Wendt $M$, Wolf KJ, Wacker F. MRI of the thorax during whole-body MRI: evaluation of different $M R$ sequences and comparison to thoracic multidetector computed tomography (MDCT). I Magn Reson Imaging 2008;27:538-45.

15. Higashi K, Ueda Y, Sakuma T, Seki H, Oguchi M, Taniguchi $M$, et al. Comparison of [(18)F]FDG PET and (201)TI SPECT in evaluation of pulmonary nodules. I Nucl Med 2001;42:1489-96. 
16. Ohno Y, Koyama H, Takenaka D, Nogami M, Maniwa Y, Nishimura $Y$, et al. Dynamic MRI, dynamic multidetectorrow computed tomography (MDCT), and coregistered 2-[fluorine-18]-fluoro-2-deoxy-D-glucose-positron emission tomography (FDG-PET)/CT: comparative study of capability for management of pulmonary nodules. J Magn Reson Imaging 2008;27:1284-95.

17. Girvin F, Ko JP. Pulmonary nodules: detection, assessment, and CAD. AJR Am J Roentgenol 2008;191:1057-69.

18. Regier M, Schwarz D, Henes FO, Groth $M$, Kooijman $H$, Begemann PG, et al. Diffusion-weighted MR-imaging for the detection of pulmonary nodules at 1.5 Tesla: intraindividual comparison with multidetector computed tomography. I Med Imaging Radiat Oncol 2011;55:266-74.

19. Chen W, Jian W, Li HT, Li C, Zhang YK, Xie B, et al. Wholebody diffusion-weighted imaging vs. FDG-PET for the detection of non-small-cell lung cancer. How do they measure up? Magn Reson Imaging 2010;28:613-20.

20. Ohba Y, Nomori H, Mori $T$, Shiraishi K, Namimoto $T$, Katahira K. Diffusion-weighted magnetic resonance for pulmonary nodules: 1.5 vs. 3 Tesla. Asian Cardiovasc Thorac Ann 2011:19:108-14.

21. Ohno $Y$, Koyama $H$, Onishi $Y$, Takenaka D, Nogami $M$, Yoshikawa T, et al. Non-small cell lung cancer: whole-body $M R$ examination for M-stage assessment-utility for wholebody diffusion-weighted imaging compared with integrated FDG PET/CT. Radiology 2008;248:643-54.

22. Mori T, Nomori H, Ikeda K, Kawanaka K, Shiraishi S, Katahira $K$, et al. Diffusion-weighted magnetic resonance imaging for diagnosing malignant pulmonary nodules/ masses: comparison with positron emission tomography. $J$ Thorac Oncol 2008;3:358-64.

23. Uto $T$, Takehara $Y$, Nakamura $Y$, Naito $T$, Hashimoto $D$, Inui $N$, et al. Higher sensitivity and specificity for diffusionweighted imaging of malignant lung lesions without apparent diffusion coefficient quantification. Radiology 2009;252:247-54.

24. Tanaka R, Horikoshi H, Nakazato Y, Seki E, Minato K, lijima $M$, et al. Magnetic resonance imaging in peripheral lung adenocarcinoma: correlation with histopathologic features. J Thorac Imaging 2009;24:4-9.

25. Luna A, Sánchez-Gonzalez J, Caro P. Diffusion-weighted imaging of the chest. Magn Reson Imaging Clin N Am 2011;19:69-94.

26. Baysal T, Mutlu DY, Yologlu S. Diffusion-weighted magnetic resonance imaging in differentiation of postobstructive consolidation from central lung carcinoma. Magn Reson Imaging 2009;27:1447-54.

27. Qi LP, Zhang XP, Tang L, Li J, Sun YS, Zhu GY. Using diffusion-weighted MR imaging for tumor detection in the collapsed lung: a preliminary study. Eur Radiol 2009;19:33341.

28. Yabuuchi H, Hatakenaka M, Takayama K, Matsuo Y, Sunami S, Kamitani $T$, et al. Non-small cell lung cancer: detection of early response to chemotherapy by using contrast-enhanced dynamic and diffusion-weighted MR imaging. Radiology 2011;261:598-604.

29. Zhou R, Yu T, Feng C, Ma L, Wang Y, Li W, et al. Diffusionweighted imaging for assessment of lung cancer response to chemotherapy. Zhongguo Fei Ai Za Zhi 2011;14:25660 .

30. Takenaka D, Ohno Y, Matsumoto K, Aoyama N, Onishi Y, Koyama $\mathrm{H}$, et al. Detection of bone metastases in nonsmall cell lung cancer patients: comparison of whole-body diffusion-weighted imaging (DWI), whole-body MR imaging without and with DWI, whole-body FDG-PET/CT, and bone scintigraphy. J Magn Reson Imaging 2009;30:298308.

31. Nomori H, Watanabe K, Ohtsuka T, Naruke T, Suemasu K, Kobayashi $T$, et al. Fluorine 18-tagged fluorodeoxyglucose positron emission tomographic scanning to predict lymph node metastasis, invasiveness, or both, in clinical T1 NO MO lung adenocarcinoma. I Thorac Cardiovasc Surg 2004; 128:396-401

32. Roberts $P F$, Follette $D M$, von Haag $D$, Park JA, Valk PE, Pounds TR, et al. Factors associated with false-positive staging of lung cancer by positron emission tomography. Ann Thorac Surg 2000;70:1154-9.

33. Nomori H, Mori T, Ikeda K, Kawanaka K, Shiraishi S, Katahira $K$, et al. Diffusion-weighted magnetic resonance imaging can be used in place of positron emission tomography for $N$ staging of non-small cell lung cancer with fewer false-positive results. I Thorac Cardiovasc Surg 2008;135:816-22.

34. Pauls S, Schmidt SA, Juchems MS, Klass O, Luster M, Reske $S N$, et al. Diffusion-weighted MR imaging in comparison to integrated [ ${ }^{1}$ F]- DG PET/CT for N-staging in patients with lung cancer. Eur / Radiol 2012;81:178-82.

35. Ohno Y, Koyama H, Yoshikawa T, Nishio M, Aoyama N, Onishi $Y$, et al. $N$ stage disease in patients with non-small cell lung cancer: efficacy of quantitative and qualitative assessment with STIR turbo spin-echo imaging, diffusionweighted MR imaging, and fluorodeoxyglucose PET/CT. Radiology 2011;261:605-15.

36. Gümüștaş S, Inan N, Sarisoy HT, Anik Y, Arslan A, Ciftçi E, et al. Malignant versus benign mediastinal lesions: quantitative assessment with diffusion weighted MR imaging. Eur Radiol 2011;21:2255-60.

37. Abdel Razek AA, Soliman N, Elashery R. Apparent diffusion coefficient values of mediastinal masses in children. Eur J Radiol 2012;81:1311-4.

38. Lin C, Luciani A, Itti E, El-Gnaoui T, Vignaud A, Beaussart $P$, et al. Whole-body diffusion-weighted magnetic resonance imaging with apparent diffusion coefficient mapping for staging patients with diffuse large B-cell lymphoma. Eur Radiol 2010;20:2027-38. 